BULLETIN Bulletin hispanique

HISPANIQUE Université Michel de Montaigne Bordeaux

113-1| 2011

Actes de 2 colloques

\title{
Paredes de versos dibujadas
}

Fábrica y materia del cartel poético barroco (1650-1700)

Inmaculada Osuna y Víctor Infantes

\section{(2) OpenEdition \\ Journals}

Edición electrónica

URL: http://journals.openedition.org/bulletinhispanique/1336

DOI: 10.4000/bulletinhispanique. 1336

ISSN: 1775-3821

Editor

Presses universitaires de Bordeaux

Edición impresa

Fecha de publicación: 1 junio 2011

Paginación: 163-268

ISBN: 978-2-86781-740-3

ISSN: 0007-4640

Referencia electrónica

Inmaculada Osuna y Víctor Infantes, «Paredes de versos dibujadas », Bulletin hispanique [En línea],

113-1 | 2011, Publicado el 01 junio 2014, consultado el 02 mayo 2019. URL : http://

journals.openedition.org/bulletinhispanique/1336; DOI : 10.4000/bulletinhispanique.1336

Tous droits réservés 


\title{
Paredes de versos dibujadas. Fábrica y materia del cartel poético barroco (1650-1700)
}

\author{
INMACULADA OSUNA \\ VÍCTOR INFANTES \\ Universidad Complutense de Madrid
}

Sur la base d'un "Inventaire" bibliographique des affiches de poésie en format double folio conservées pour les années 1650-1700, sont définis leurs traits distinctifs : modalités éditoriales, contenus thématiques et culturels, voies de lecture et de diffusion, caractéristiques littéraires.

Sobre un "Inventario" bibliográfico de los carteles poéticos de doble folio conservados del periodo 1650-1700, se establecen las características de los mismos: modalidades editoriales, contenidos culturales y temáticos, tipologías de lectura y difusión y características literarias.

The authors make an inventory of large folio Spanish poetic posters between 16501700. They study their characteristics, different printing models, cultural contents, themes, ways of reading, diffusion and literary features.

Mots-clés : Affiches poétiques - Poésie espagnole du $17^{\mathrm{e}}$ siècle - Lecture de poésie publique - Bibliographie.

Bulletin Hispanique, Tome 113, n 1 - juin 2011 - p. 163 à 238. 


\section{BULLETIN HISPANIQUE}

\section{Para Blanca Periñán y Juan Montero, dolida ausencia, de su memoria llena.}

«El Valor del Valor habla elocuente, y en públicos Carteles ha fijado, «Pared en blanco, papel de necios». sustentará con ánimo valiente, que ay vn valiente en todo consumado.»

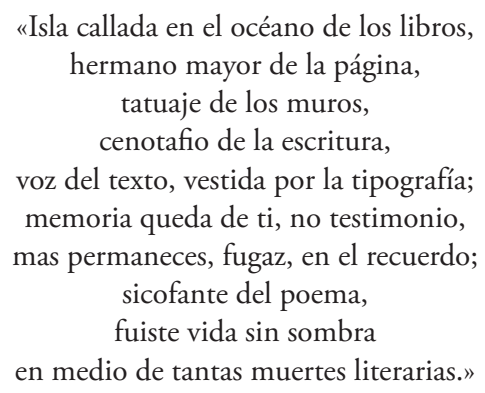

L os libros se imprimen por muchas razones, los carteles por una sola; si damos un paso atrás, las obras literarias de cierta extensión, poéticas para las señas de esta congregación, se escriben por numerosos motivos (algunos ciertamente inconfesables), los carteles, por uno solo (casi siempre diáfano). Vamos, pues, en el inicio, con algunos necesarios cómputos y porcentajes para saber con quiénes nos jugamos este lance bibliográfico. Libros de esta media centuria que nos ocupa, 124 se han sumado al detalle ${ }^{1}$ y no hay inconveniente en añadir un $20 \%$ más entre ignotos, trasgos y sorpresas; pliego sueltos de «a cuarto», a la baja unos 450 , porque a la alta nos vamos más allá de las cuatro resmas cumplidas; hojas sueltas de "a folio", conocemos cerca de 100 y de doble folio algo más de la mitad, y hemos parado de sumar porque se nos echaba el tiempo encima, por ello no hay la menor duda de que deberíamos ańadir un $50 \%$ cumplido. Oséase, que poniéndonos en la orilla de los números, la emoción lectora la dejamos para quien tenga más tiempos y más ganas, los «cuerpos de libros» líricos andarán por los 150 y en el caso de la «resmillería» coplera al por mayor añadiríamos un cero, y nos quedaríamos cortos. Y todo este mercado de papel poético esta producido (prácticamente) por las mismas 22 imprentas que vivían de darle al tórculo

1. El muy completo «Listado de poesía impresa entre 1650 y 1700» inserto en Ignacio García Aguilar, ed., Tras el canon. La poesía del Barroco tardio, Vigo, Academia del Hispanismo, 2009, p. 231-243, aparece sin nombre de recopilador, y en estas ocasiones es de ley culpar al editor de su presencia. 
trovadoresco, llámense los vates don Francisco de Quevedo, que Dios guarde, o don José de Ogazón Angulo, que el Parnaso pierda.

Por todo ello se vislumbra que hay muchos bardos áureos, pero pocos, poquísimos cartelistas, al menos de vocación y profesión confesada (aunque como dejó escrito un poeta reincidente: «Quien esté libre de soneto, / que tire el primer endecasílabo»). La poesía en libro y en pliegos se escribe con el empeño de satisfacer la inspiración y el deseo de ser leída (y vendida y, a ser posible, comprada); el cartel se gesta por la necesidad, o la conveniencia, de comunicar un acontecimiento y, aun cuando se le incluyan los versos, en mayor o en menor cantidad prima la intención de transmitir una información, en la mayoría de los casos, asociada a una circunstancia que conviene ser conocida de una manera pública y general. La poesía demanda lectores individuales, silenciosos y recogidos; el cartel reclama la multitud a su frente, las voces elocutivas y el talante sonoro. El libro y el pliego llevan sus jornadas de trabajo y cuestan lo que marca la «Tassa» (cuando la llevan), el cartel se despacha a media mañana y no hemos visto todavía ninguno con el precio (sin IVA); los libros y los pliegos permanecen, a veces a su pesar, los carteles son ilusiones impresas de pocas horas, pasto del olvido y, si acaso, de la memoria. Cualquiera de nosotros ha leído (espero) bastantes libros e impresos menores, pero, a cambio, ha visto (y leído) miles de carteles, aunque ya no se hagan poéticos ni (apenas) literarios; por el recuerdo lector de un libro, debemos multiplicar por algún que otro digito el de los carteles que han pasado ante nuestros ojos a lo largo de nuestra vida literaria. Somos pues, pupilos de los carteles y vástagos ojeadores de su presencia.

En la media centuria que nos ocupa el asunto editorial y lector andaba por los mismos caminos, libros, los menos, pliegos, los más, pero carteles de todo tipo inundaban las calles y plazas con la información diaria de una sociedad lectora ya suficientemente asentada en esta segunda mitad del siglo $\mathrm{XVII}^{2}$. Entre esta proliferación abusiva y constante de Pragmáticas, Edictos, Informaciones, Cartas, Pronósticos, Porcones, Cédulas, Alegaciones y demás formas editoriales «ocurrentes», «recurrentes» $\mathrm{y}$ "propias» que circulaban a diario por las ciudades españolas ${ }^{3}-\mathrm{y}$ se ha definido esta presencia como «espacios

2. Vid. el interés reciente sobre la época y la producción poética en el colectivo citado en la nota precedente, al que podemos sumar el de Antoni L. Moll y Joseph Solervicens, La poètica barroca a Europa. Un nou sistema, espistemològic i estètic, Barcelona, Punctum \& Mimesi, 2009.

3. A las primitivas clasificaciones de Jaime Moll, «Los surtidos de romances, coplas, historias y otros papeles», en Enrique Rodríguez Cepeda, Actas del Congreso RomanceroCancionero, Madrid, José Porrúa, 1990, t. I, p. 205-216; luego recogido en su De la imprenta al lector. Estudios sobre el libro español de los siglos XVI al XVIII, Madrid, Arco/libros, 1994, p. 45- 
y formas de la publicidad del escrito» ${ }^{4}-$, los carteles poéticos apenas han merecido unas líneas en la vastísima bibliografía de la poesía áurea españo$1 a^{5}$. Pero digamos cuanto antes qué entendemos por un "cartel» y hagamos una partición técnica (y nunca mejor dicho:) formal, harto necesaria para nuestros propósitos.

El modelo de cartel (de carteles) que nos interesa está mayoritariamente impreso $^{6}$. No nos cabe la menor duda de que debieron existir manuscritos, más cercanos (quizá) al pasquín, al libelo y al panfleto ${ }^{7}$-sin olvidar el pariente

56, hemos puesto comentario y ampliación en Víctor Infantes, «La tipología de las formas editoriales», en Víctor Infantes, François Lopez y Jean-François Botrel, Historia de la edición y de la lectura en España 1472-1914, Madrid, Fundación Germán Sánchez Ruipérez, 2003, p. 39-49, y en «Las formas editoriales (1604-1605)», en José Manuel Lucía Megías, Imprenta, libros y lecturas en la España del Quijote, Madrid, Ayuntamiento de Madrid, Imprenta Artesanal, 2006, p. 383-428.

4. Vid., especialmente Antonio Castillo Gómez y entre otros trabajos suyos sobre el tema («Artificios epigráficos. Lecturas emblemáticas del escribir monumental en la ciudad del Siglo de Oro", en Víctor Mínguez, Del libro de emblemas a la ciudad simbólica. Actas del III Simposio Internacional de Emblemática Hispánica (Castellón-Benicàssim 30 de septiembre, 1 y 2 de octubre de 1999), Castellón, Universitat Jaume I, 2000, t. I, p. 151-168; «Leer en la calle. Coplas, avisos y panfletos áureos», Literatura: teoría, historia, crítica, no 7, 2005, p. 15-43; «Cultura escrita y espacio público en el Siglo de Oro», Cuadernos del Minotauro, no I, 2005, p. 33-50; etc.), Antonio Castillo Gómez, Entre la pluma y la pared. Una historia social de la escritura en los Siglos de Oro, Madrid, AKAL, 2006, p. 203-251.

5. Ahí quedan, señeras, las 14 entradas del artículo de José Simón Díaz, «Algunos carteles poéticos del Siglo de Oro», Cuadernos Bibliográficos, no 44, 1982, p. 201-203; en sus otros trabajos sobre lo que denomina "poesía mural», hay que extraer, indirectamente, la información, casos de La poesía mural en el Madrid del Siglo de Oro, Madrid, Ayuntamiento de Madrid, 1977; «Difusión de la poesía mural en la España del Siglo de Oro» de 1978, que se quedó inédito; «La poesía mural del Siglo de Oro en Aragón y Cataluna», en Homenaje a José Manuel Blecua, Madrid, Gredos, 1983, p. 617-629; «La poesía mural: su proyección en universidades y colegios», en Homenaje al profesor Francisco Ynduráin. Estudios sobre el Siglo de Oro, Madrid, Editora Nacional, 1985, p. 479-497 y «La literatura mural», en José M. ${ }^{\text {a Díez }}$ Borque, Culturas en la Edad de Oro, Madrid, Universidad Complutense, 1995, p. 169179. Sólo merece añadir la recopilación de Pedro M. Cátedra, «Movimientos espirituales y clientelismo político: a propósito de pliegos y carteles poéticos del siglo XVII en la Biblioteca Universitaria de Salamanca», Revista Portuguesa de História do livro, nº I, 2, 1987, pp. 89-140, aunque no se acomoda a nuestra cronología, pues el único que cae hacia nuestras fechas es el $\mathrm{n}^{\circ} 3$, p. 133-134, es poético, pero está en latín. Las palabras que nosotros les dedicamos hace algún tiempo irán citadas, como debe, más adelante.

6. Huelga decir, a tenor de la bibliografía ya citada, que los estudios clásicos sobre el cartel no hacen referencia alguna anterior a 1870, fecha (aproximada) del (re)nacimiento del poster moderno; baste, por ello citar el estudio ancilar de John Barnicoat, Los carteles: su historia y lenguaje (1972), Barcelona, Gustavo Gili, 1973.

7. Vid., para estas otras formas de «literatura en la calle», José M. a Díez Borque, «Literatura en la calle. Prosa y poesía en las paredes: pasquines del Siglo de Oro espańol (I)», Bulletin 
manual del graffiti ${ }^{8}$-, pero de las medidas que luego vamos a acotar, y aunque no sea de nuestros años, apenas conocemos (y conservamos) testimonios, como los de una justa poética sevillana de 1615, A la Purísima concepción de la Santísima Virgen María... dedican debidos honores los Hermanos Nazarenos de la Insigne Cofradia de la Santísima Cruz in Jerusalem; una Glossa anónima ([Cuarteta] «Pues tras un tamaño olvido / volviendo en si, y por premiaros» y [Glosa] «Prendió un tiempo a la justiçia, / la iniustiçia, y a la fama»), escrita en Valladolid, en abril de 1631 a la muerte de Antonio Pichardo Vinuesa, Catedrático de Derecho de la Universidad de Valladolid, Oídor de la Real Cancillería y eminente jurista ${ }^{9}$ y poquito(s) más. Si la cometa literaria del cartel poético impreso es en verdad efímera, el manuscrito es una estrella fugaz en el firmamento de la poesía áurea.

La palabra cartel no es un término técnico de imprenta, el castellano lo toma del italiano 'cartello' (de 'carta'), pero su uso práctico se impuso paulatinamente al original de atlas, que es el primero de los formatos originales de los llamados "géneros perfectos» de la fábrica de las páginas; tan común y tan evidente es su concepción, una hoja de papel sin plegar con una sola impresión, que no figura en el tratado primordial de Víctor Alonso de Paredes, pues el género perfecto, "que es el común, y que estilan en casi todas las impresiones», empieza en el siguiente, cuando se ha producido ya el primer doblez, es decir: el folio ${ }^{10}$. Dijimos hace tiempo que la historia de la imprenta empieza con los impresos de una sola hoja, y como seguimos pensando lo mismo y nadie nos ha contradicho, por impreso de una sola hoja entendemos aquel que solo tiene impresa una de sus caras, en lo que denominamos habitualmente el recto de una hoja de papel ${ }^{11}$. Se necesita un solo molde de

of Hispanic Studies, LXXII, no 4, 1995, p. 365-384, y los trabajos, ya citados, de A. Castillo Gómez.

8. Hay suficientes materiales en el colectivo editado por F. M. Gimeno Blay y M. ${ }^{a}$ Luz Mandingorra Llavata, "Los muros tienen la palabra». Materiales para la historia de los graffiti, Valencia, Universidad de Valencia, 1997.

9. Se trata de 1 h. manuscrita, a dos cols., doble fol. (310 x $400 \mathrm{~mm})$, Valladolid, Archivo Histórico Provincial, Protocolos, Legajo 2.084, que milagrosamente alguien usó como papel reaprovechable para separar dos ańos de los documentos del escribano Juan de Filgueira y así se salvó de su destrucción; en otro sitio y lugar ya diremos quién era este Juan de Pichardo y por qué mereció, y va a merecer, nuestra atención.

10. Vid. Alonso Víctor de Paredes, Institución y origen de la Imprenta y reglas generales para los componedores, Jaime Moll, ed., con «Una nueva noticia editorial» de Víctor Infantes, Madrid, Calambur Editorial, 2002, fol. 23v.

11. Víctor Infantes, «Historia mínima (y desde luego incompleta) de los impresos de una sola hoja. I. Los primeros tiempos de la imprenta», Litterae. Cuadernos sobre cultura escrita, $\mathrm{n}^{\circ}$ 1, 2001, p. 137-144 [y, también sin paginación, como encarte exento]; luego recogido en Víctor Infantes, Del libro áureo, Madrid, Calambur Editorial, 2006, p. 113-120. 
composición, aunque se inserten en él tipos, adornos y grabados, es decir: texto e ilustraciones -sólo en un caso de los que luego veremos figura una plancha de cierto tamaño y se señala en el pie que fue «dibuxada, y abierta la estampa por el mismo autor» [ $\left.\mathrm{n}^{\circ} 31\right]$-, y la imposición se efectúa directamente en la forma, que en palabras de Martín Abad «constituye en términos de bibliografía material la unidad mínima de impresión» ${ }^{12}$. Estamos, pues, ante el prototipo de todos los modelos posteriores: la simple hoja impresa solamente por una de sus caras, que produce un primer e iniciático modelo de impreso: el atlas, que enseguida ocupará la demarcación editorial del (propio) atlas, del mapa, de la vista, de la estampa y, especialmente para nuestro interés, del cartel. (Los primeros trabajos conocidos de Johannes Gensfleisch de Gutenberg, por hacer una cita señera que no admite dudas y sin entrar en su supremacía sobre la invención (y la aplicación efectiva) de los tipos móviles, nos hablan de ciertas obras de una sola hoja: un Kalender astronómico para 1448 y dos Bulas de 1454, una de Indulgencia del Papa Nicolás V y otra para la Cruzada contra los turcos.)

Esta sencilla operación técnica está aliada con la medida del papel. La dimensión esencial del papel de impresión a lo largo de todo el siglo XVI y XVII, es la del llamado "papel de tina", por el molde donde se fabricaba, y de donde sale, con algún que otro vericueto léxico/semántico, el que sea San Juan Evangelista el patrón de los impresores, por su martirio romano en la tina de aceite hirviendo, colocada ante Portam Latinam ${ }^{13}$. Éste era generalmente de unos $32 \times 44 \mathrm{~cm}$-aunque hay algunos papeles italianos y franceses usados en Aragón y Cataluña en el siglo XVII que alcanzan los 40 x 60 cm-, se realizaba a mano y era una medida estándar en casi toda Europa; es el tamaño denominado habitualmente de «marca», "plano» o "plano regular».

Esta es la hoja básica usada en todas las imprentas europeas, el llamado (editorialmente hablando): pliego, que sin doblar al centro correspondía al formato atlas, con un solo plegado nos da el formato folio, dos el formato cuarto, tres el octavo y cuatro el dieciseisavo (etc.). Más importante que la medida del papel -para nuestro interés ahora- es la medida de la forma en la prensa manual, porque es allí donde se impone el molde ya compuesto. La extensión que hay en el hueco del cofre para colocar la forma es de 51 x $62 \mathrm{~cm}$, de los

12. Vid. Julián Martín Abad, «La técnica impresora», en José Manuel Lucía Megías, Aqui se imprimen libros. La imprenta en la época del Quijote, Madrid, Imprenta Artesanal/Ollero y Ramos, 2005, p. 11-33, en particular, p. 23.

13. Vid., con más extensión esta aventura apelativa, Víctor Infantes, «La santidad tipográfica en la España del Siglo de Oro. Las honras poéticas a San Juan Evangelista, Patrón de los Impresores", Peninsula. Revista de Estudos Ibéricos, no 2, 2005, p. 251-296, en particular, p. 253. 
que hay que descontar la rama o bastidor que sujeta la forma, es decir unos $3 \mathrm{~cm}$ por cada lado, más otros $2 \mathrm{~cm}$ del marco del molde con lo que quedaría, aproximadamente, $46 \times 57 \mathrm{~cm}$; éstas son medidas de la prensa construida por y para la Imprenta Artesanal, comparadas con las prensas originales del siglo XVI en el Museo Plantiniano, que son las más antiguas conservadas en la actualidad y que ya tienen el sistema de Blau, el de dos vástagos que flanquean el husillo ${ }^{14}$. Es decir, que la medida del papel de $32 \times 44 \mathrm{~cm}$ deja espacio de sobra para maniobrar sobre la forma y, además, queda tapado por la frasqueta, por tanto, la medida real posterior del papel ya impreso dependerá del corte que se quiera ejecutar, si es que se decide guillotinar y no se prefiere conservar en rama. Nos caben pocas dudas que las prensas españolas de esta segunda mitad del siglo XVII deberían ser muy semejantes a la citada y los datos que ofrecemos se acercan bastante a la primera medida espańola ofrecida por Juan Joseph Sigüenza y Vera a comienzos del siglo XIX en su Mecanismo del Arte de la Imprenta, donde nos dice que tiene «tres pies menos cuarto con todas, ancho dos pies», es decir, unos $55 \times 76 \mathrm{~cm}^{15}$ actuales.

Claro está que también el cartel puede ser medio cartel (y sigue siendo un cartel), ocupando tan sólo la mitad de la hoja, es decir, dos planas de impresión, generalmente -y por una cierta obviedad gráfica y visual de dónde se va a difundir- en el recto de la misma. Puede, entonces aprovecharse el espacio disponible para componer dos obras diferentes, o la misma por duplicado para ahorrar papel y tirada; es fácil de corroborar, pues conservamos (milagrosamente) algunos pliegos originales con la imposición de las dos formas en paralelo. Estas piezas solían imprimirse (sólo) en el recto de una hoja, en las dos modalidades: vertical, dos formas continuadas en posición superior/inferior, y horizontal: dos formas consecutivas y a veces especulares (o, también, invertidas) al centro; en cualquier caso, siempre una hoja única de impresión. A estos carteles en folio, de los que hemos controlado cerca de un centenar poético para los años que nos ocupan, hemos preferido exiliarlos de nuestras consideraciones, no sólo por su elevado número-que excede sobradamente un trabajo como el presente-, sino por centrarnos en sus hermanos mayores, los que consideramos auténticos carteles: es decir, los de doble folio, más desatendidos y menos divulgados y, claro está, más

14.Vid. el fascinante desarrollo de la construcción de esta prensa en Bernardo López Lozano, «Proceso de fabricación de la prensa» y José Bonifacio Bermejo Martín, «La prensa de imprimir de madera», en J. M. Lucía Megías, Aqui se imprimen libros, p. 153-160 y p. 161166. (Allí estuvimos, emocionados, en su montaje.)

15. Madrid, Imprenta de la Compañía, 1811, ed. facsímile de Madrid, Almarabú, 1992, encarte, con dibujo, entre p. 152-153. 
puñeteros de documentar. En algunos casos hemos podido comprobar la imposición de dos moldes en folio en donde no queda claro, desde el punto de vista de su concepción original, si se trataba de una doble tirada de un impreso en folio o si se había diseñado como un doble folio original al que luego se le han incluido variantes de composición para convertirlo en cartel, algún ejemplo veremos a continuación.

Ya indicamos hace algún tiempo ${ }^{16}$ que el cartel se convertirá en un universo gráfico donde van a ir incorporándose lentamente los organigramas de la información y de la difusión pública de los estamentos de la sociedad áurea, y con ellos (y entre ellos) la presencia visual de la poesía, exiliada (y libre gráficamente) de la monotonía repetitiva de la paginación. A la fuerza tenemos que adelantar (y confesar) que lo hoy conservado de esta categoría es un pálido testimonio de lo que debió imprimirse a lo largo de estos años, pues la dificultad de conservación de este efímero material no permite contar más que con ejemplares escasísimos de su proliferación, y la verdad y en muchas ocasiones, bastantes maltrechos y malheridos en su constitución. Algunos volúmenes de varios, que congregan manuscritos e impresos, acaso por la perseverancia de algún coleccionista anónimo o conservados por algún fin testimonial específico: religioso, legislativo, universitario, municipal, etc. y..., poco más. A veces, insólitos ejemplares insertos (y doblegados) en los documentos más impredecibles, la aparición esporádica de alguna pieza en una subasta o la sorpresa de un enmarque en una biblioteca, en un archivo, en un monasterio, en la sacristía de una iglesia: «se fixe [el cartel] en la sacristía de cada Iglesia, donde esté de manifiesto a todos, y que ninguna persona le quite, ni rompa, so pena de excomunión mayor», reza un cartel del Arzobispo de Sevilla ${ }^{17}$. (Es deporte bibliográfico que practicamos esporádicamente el de encontrar carteles en atrios, refectorios y pasillos de residencias conventuales, con sorpresas como el maravilloso cartel, impreso sobre seda, en el Convento de las Huelgas burgalés con las obligaciones de la novicias, que no traemos

16. Repetimos ahora, sólo en parte, lo ya expuesto en un trabajo donde abordamos estos asuntos, Víctor Infantes, «Historia mínima (y desde luego incompleta) de los impresos de una sola hoja. II. Los años áureos», en Anthony Close, Edad de Oro Cantabrigense. Actas del VII Congreso de la Asociación Internacional del Siglo de Oro (AISO) (Robinson College, Cambridge, 18-22 de julio de 2005), Madrid, AISO, 2006, p. 351-356; luego recogido, con modificaciones, en Víctor Infantes, Del libro áureo, Madrid, Calambur Editorial, 2006, p. 121-135, y donde (también) prometimos continuarlos.

17. Citamos la pieza, por el rigor de la cita, aunque hay otras muchas parecidas, en Pedro de Tapia, Arzobispo de Sevilla [...], Sevilla, a 4 del mes de Junio de 1657 (¿Sevilla?, s. i., ¿1657?), una hoja impresa, doble fol. (290x440 mm), a línea tirada, con inicial xilográfica, firma autógrafa del Arzobispo y del Escribano. 
al powerpoint por ser de época posterior, así como los también sedosos de las fiestas salmantinas de estudiantes y congregaciones.)

Desde los primeros decenios del siglo XVI empiezan a aparecer los carteles con anuncios de los programas universitarios (Zaragoza, Salamanca, etc.); con sugerentes disputas filosóficas, canónicas y teológicas, generalmente en latín, que se exhibían para promover la disputatio y la respuesta (a veces también impresa), como el prodigioso grabado calcográfico de la machinae de Martín Diest ${ }^{18}$, que no nos resistimos a citar; o como el anuncio de querer trasladar una "guerra literaria» contra el (anti)aristotelismo de Lope de Vega y la Spongia a las paredes del Madrid de los Austrias ${ }^{19}$; con textos poéticos desgajados de las Justas y donde (también, pero no siempre) se recluyeron en libro, o exentos (e irrepetibles) en su constitución única como plasma gráfico para su lectura en la calle ${ }^{20}$. A veces solitarios ejemplos de poesía gráfica y visual que rompen los moldes métricos y alcanzan las demarcaciones del laberinto, el schematograma, el caligrama y demás formas figuradas ${ }^{21}$; con las noticias de esas mismas Justas -a veces impresas en «raso blanco», como nos recuerda Lope de Vega para las madrileńas de San Isidro de $1622^{22}-$, infor-

18. Vid. la reproducción y estudio de Ángel San Vicente, Una cartela de tesis dedicada a la Virgen del Pilary Reino de Aragón en 1639, Zaragoza, Centro de Documentación Bibliográfica Aragonesa, 1990. (Es evidente que obviamos los carteles sólo con ilustración, independiente del tipo de grabado utilizado, a menudo (todavía) xilográfico, pero éste incluye un juego gráfico/textual muy significativo.)

19. Vid. Joaquín de Entrambasaguas, «Una guerra literaria del Siglo de Oro. Lope de Vega y los preceptistas aristotélicos", Boletín de la Real Academia Española, no XIX, 1932, pp. 13560, p. 260-326; no XX, 1933, p. 405-444, p. 569-600, p. 687-734; no XXI, 1934, p. 82-112, p. 238-272, p. 423-62, p. 587-628 y p. 705-857, con reproducción (encartada) a su tamańo; mientras que en la tirada exenta, Madrid, 1932, aparece reducido, p. 160.

20. Conservamos, como raro ejemplo, uno de la Cofradía de la Virgen del Rosario vallisoletana, vid. Víctor Infantes, "Devotio in propatulo: un cartel poético desconocido de la Cofradía del Rosario de Nuestra Señora (c. 1545) (I)», Via Spiritus. Revista de História da Espiritualidade e do Sentimento Religioso [Lecturas e espiritualidade na Peninsula Ibérica na Época Moderna], no 4, 1977, p. 243-251.

21. No es lugar de arrojar los testimonios ni toda la bibliografía pertinente, valga rememorar algunos títulos donde moran los ejemplos; así, las primitivas aportaciones de José Simón Díaz, ya citadas; Rafael de Cózar, Poesía e imagen. Formas difíciles del ingenio literario, Sevilla, El Carro de Nieve, 1991; José María Díez Borque, Literatura de la celebración. Verso e imagen en el Barroco español, Madrid, Consorcio Madrid Capital Europea de la Cultura, 1992 y Verso e imagen. Del Barroco al Siglo de las Luces, Madrid:, Comunidad de Madrid, 1993 (y en él, Fernando R[odríguez]. de la Flor, «El régimen de lo visible. Género y figuras de la poesía visual de los siglos XVII y XVIII», pp. 265-280), etc.

22. Así, en la Relación de las Fiestas que la insigne Villa de Madrid hizo en la Canoniçación de su Bienauenturado Hijo y Patrón san Isidro, con las Comedias que se representaron y los Versos que en la Justa Poética se escriuieron (Madrid, Viuda de Alonso Martín, 1622, 4º, 
mando a los pretendientes a poetas públicos de los «certámenes», los premios, los modelos estróficos y temáticos (y las quejas religiosas: «atendiendo más a esto que a lisonjear al oído con la vana composición de carteles y certámenes poéticos, que del púlpito» ${ }^{23}$ ); con la representación de los primeros calendarios de pared, de los que hoy contamos con el de Gerónimo Ortiz para $1628^{24}$ y medio almanaque de Miguel Márquez para 1654; con la ordenada planimetría paralela de las barajas ocupando su superficie ${ }^{25}$; con desplegables pegados como el Cathálogo de los libros que se prohiben, ansí en Latín como en Romance $^{26}$, para situar en las puertas de las librerías; con la exhibición del orgullo tipográfico recogido en la prodigiosa cartelería en honor del Patrón de los Impresores, San Juan ante Portam Latinam ${ }^{27}$; con decenas de premáticas (sobre el precio del pan, sobre el uso de los cotos de caza, sobre el decoro de los vestidos, sobre el control de las armas, etc.) de conocimiento necesario, dando a la letra impresa el valor icónico de la palabra regia, legal y eclesiástica, fijadas en su permanencia gráfica impresa, dentro del perímetro de esa «ciudad letrada y escrituraria» de la que nos habla Ángel Rama ${ }^{28}$.

28 hs. +156 fols.), en los preliminares; hay otros muchos testimonios parecidos, pero en este caso hemos desarrollado la mención, Lope es Lope.

23. Tomamos la cita de Autoridades, que la toma del Padre Alonso Ortiz de Ovalle, Histórica relación del Reino de Chile (Roma, Francisco Cavallo, 1646, 4º, 4hs. +455 pp. +9 hs. +6 planos+1 mapa+23 láms.), y vale así.

24. Vid. Luis Gutiérrez Ortiz, Pronóstico y calendario de 1628 (Valladolid, Gerónimo Morillo, 1627, Anastasio Rojo, Víctor Infantes y Jaime Moll, Madrid, Memoria Hispánica, 1997, con reproducción a su tamańo (y Jaime Moll, «El privilegio del calendario anual en el siglo XVII», en Las relaciones de sucesos en España (1500-1750) Actas del Primer Coloquio Internacional (Alcalá de Henares, 8, 9 y 10 de junio de 1995), María Cruz García de Enterría, Henry Ettinghausen, Víctor Infantes y Augustin Redondo, eds., Alcalá de Henares, Universidad de Alcalá de Henares/La Sorbonne, 1996, p. 253-259.)

25. Suficientes testimonios en su mayoría xilográficos, aunque hay más de los ahí recogidos, ofrece Félix Alfaro Fournier, Los Naipes. Historia general desde su creación a la época actual. Museo Fournier, Vitoria, Heraclio Fournier, 1982, que sirven (de paso) para comprobar la evolución de las medidas de las hojas de impresión; ahora hay que añadir Francisco Mendoza Díaz-Maroto, "Hallazgos de barajas antiguas españolas», The Playing-Card, no XXXIV, 4, 2006, p. 269-284.

26. Vid. J[esús]. M[artínez]. de Bujanda, V. Index de l'Inquisition espagnole 1551, 1554, 1559, Québec, Université de Sherbrooke/Droz, 1984, con la reproducción entre p. 686-689, definido como "planche dépliante».

27. Vid. V. Infantes, «La santidad tipográfica», cit., con reproducción de (casi) todos los conocidos hasta la fecha, p. 283-294, de los años 1683 y 1689; pero nos faltan otros muchos y de otros muchos años, como los sevillanos de 1674, guardados en volumen que manejó Santiago Montoto y que hoy se halla en paradero desconocido, $c f$. V. Infantes, «La santidad tipográfica», cit, p. 268-269.

28. Vid. Ángel Rama, La ciudad letrada, Hannover, Ediciones del Norte, 1984, claro está 
En muchas ocasiones orlados con dos o tres carriles de piezas, con injerencias ilustrativas e icónicas injertadas en la manchas uniformes del texto, fracturando su geometría plana para destacar la preponderancia del mensaje escrito, que se encuentra destinado a un primer contacto visual que empuja a su lectura silenciosa (y extática), cercano a lo que Régis Debray denomina la mirada de la "transmisión simbólica» ${ }^{29}$; aunque en el caso de los dedicados a San Juan Evangelista, que luego mencionaremos, se logra componer un universo iconográfico de impresionante complejidad espacial y figurativa, a modo de una escenografía tipográfica, que en algunas ocasiones se disemina como una estructura apofática, donde se revela la anamorfosis de un prodigioso caligrama. Textualidad comprimida de su silencio ortofónico que se convierte en información y poesía mural, gramática y poesía para ver, texto y verso que requiere la congregación de la lectura pública; a diferencia del libro, el cartel reclama la lectura inmediata, sugiere un contenido necesario, exhibe (efímeramente) el texto antes del olvido. El registro actual de lo conservado, con nuestro confesado lamento de su escasez, no está a la altura de lo que existió; por un lado, se multiplican las citas de las piezas que no han llegado hasta nosotros y, por otro, nos queda la incógnita de las muchas muestras que tal vez no llegaremos nunca a conocer. Documentos editoriales a menudo ignorados en los repertorios, desasistidos de su materia tipográfica por el contenido textual de sus contenidos y, en general, velados en su significación testimonial para muchos panoramas críticos; pero también fósiles gráficos del propio texto, elevados a la supervivencia lectora en la de la geografía impresa de su constitución, como una cartografía reticular donde habita la poesía. En esta turba editorial los carteles poéticos representan una singular congregación de ilusiones literarias, elevadas a la categoría de documento público por quienes los financian y los editan y sancionadas por unos lectores asiduos que mantienen su producción. No extraña, entonces, la anonimia general de estos especímenes literarios, frente a la cita de algunos escasos nombres que sólo afilaron la pluma para estas ocasiones, o que la mayoría de estas obras sean solitarios testigos de un instante creativo (y social o religioso) y que no tuvieran más recuerdo literario posterior que su olvido.

Tres últimos problemas, en nada menudos, quedan por reseñar de estos pósters barrocos versificados, que pueden dividirse en dos modelos generales: carteles informativos, que es su uso básico, con predominio del texto, sin apenas composiciones complejas, algunos adornos a lo sumo (orlas que los (en)

que para América Latina, pero con un finísimo análisis que puede extrapolarse en las mismas fechas áureas para Espańa, $c f$., especialmente, los capítulos 2 y 3 .

29. Vid., Régis Debray, Vida y muerte de la imagen. Historia de la mirada en Occidente [1992], Barcelona, Paidós, 1994, en particular, p. 41-63. 
cierran, divisiones internas con filetes, separación con plecas de partes de la obra, etc.) -aunque lo de «informativos» tiene su aquel semántico tratándose de poesía-, y carteles ornamentales, con escaso texto y profusión o superposición de la geometría tipográfica, dejando aparte aquellos en que la composición, por su concepción eminentemente visual, requiere de antemano unas disposiciones planimétricas nodales específicas: laberínticas, acrósticas, circulares, etc. Los porcentajes de los estudiados andan con una leve primacía para los segundos, porque cumplen de este modo no sólo su función básica de informar, sino que sirven esa información envuelta en un atractivo diseño editorial que potencia la atención y pretende generar su lectura.

En primer lugar, existe un doble problema de asignación tipográfica, pues muchos de ellos carecen de señas editoriales y de fecha de impresión. En algunas ocasiones es posible un análisis comparativo de ciertos elementos editoriales: tipografía, grabados, etc., que permiten atribuir su impresión -siempre con precauciones- a un taller determinado; así, en los más de cincuenta que manejamos, casi el $40 \%$ es madrileńo y otro tanto carecen de adjudicación segura, el $10 \%$ restante se lo reparten Granada (60 \%), Sevilla $(10 \%)$, Barcelona (10 \%), Zaragoza (10\%) y Valencia (10 \%). Por lo que conocemos, y a diferencia de los libros y los pliegos, los carteles parecen ser productos de determinados talleres, por lo menos en lo llegado hasta nuestras manos, aunque se nos hace muy difícil pensar que no se imprimieran en otros lugares (Salamanca, Valladolid, etc.) de los que no han quedado (de momento) testimonios editoriales. Asimismo, en algunas ocasiones es fácil suponer su silenciosa cronología al hilo de las referencias que motivan su edición: casamientos y necrológicas regias, conmemoraciones sociales y religiosas, etc. Tan sólo en una ocasión hemos querido corroborar la existencia de un nueva edición de alguno de los carteles, caso de la segunda composición de incluida en las Dézimas, en donde resumidos están los sermones, que predican en sus Missiones por toda España [no 29]: «Piensa que te has de morir, I piensa que ay Gloria, e Infierno", aparecido ya en el siglo XVIII con el título de Décimas a la muerte compuesta por un lastimado corazón (Sevilla, Viuda de Francisco Leefdael, s. a., pero hacia ¿1730?; doble fol. 315 x 410 mm), quizá por tratarse de un tema devocional no sujeto a la cronología de ningún acontecimiento ${ }^{30}$. En ocho ocasiones aparecen impresos con «Licencia», trámite, que por otra parte y en teoría, había que solicitar en todos los casos, aunque quizá se trate de una exigencia más controlada cuando son productos que

30. El texto es el mismo hasta la estrofa no 7 («Apriessa no se han de hazer / cosas que importantes son»), pero a partir de aquí inserta cinco estrofas más, alternando con las décimas de nuestro cartel; nuestro edición contiene 15 décimas en tres columnas y la edición sevillana 20 en cuatro, hay edición facsímile de Madrid, El Crotalón, 1986. 
se piensa vender, caso muy especial representa la notación manuscrita que figura al pie de las Coplas en alabanza de la Inmaculada [no 50]: "Ynprimase con que no sean las siete últimas coplas y con que se traiga la copia para ver si coresponde [sic] con su original». Sólo en dos de ellos, el Sumario [no 49] y las Glosas [ $\mathrm{n}^{\circ} 31$ ] figura el consabido «véndese en casa de» y puede tratarse, por su contenido devocional, de carteles para comprar y conservar en la casa, pues en el caso de las Glosas, con primeras y segundas partes, conocemos ediciones anteriores que aseguraban su éxito comercial; en el cartel a la muerte de Carlos II [no 21] se señala que " Hallaráse en la Imprenta [no se señala cuál, pero suponemos la Imprenta Real], enfrente del Correo de Italia» ${ }^{31}$, lo que expresa claramente la posibilidad de adquirir el delirio matemático de don Jerónimo de Ares Vaamonde, Alférez Mayor de la Villa de Ponferrada (eso sí, sin ábaco para la comprobación numérica). Igualmente en cuatro casos, y los cuatro son de carácter religioso, se señala explícitamente que han sido editados «sub correctione» eclesiástica, uno de ellos es el enigmático recitativo de Los claveles y rosas [no 35] y los otros son obras son de Diego Ramos del Castillo, dos sobre la beatificación de Santa Rosa de Santa María, una para la justa poética [ $\left.n^{\circ} 44\right]$ en su honor -de la que conservamos el cartel de la convocatoria en 1669-, otra para su Octava en Santo Domingo cantadas por la Capilla Real de Madrid [no 43] y la última unas Redondillas a la Concepción [no 45].

En segundo lugar, desconocemos su tirada habitual, porque necesariamente ningún taller estaba obligado -salvo algún contrato muy específico-a tener que tirar mil o mil quinientos ejemplares para los que daba de sí la jornada de imprenta; pensamos que dada la facilidad de su impresión, no tiene retiración y la composición, por complicada que sea en algunas ocasiones, es otro asunto, no debía superar la resma, es decir, los 250 ejemplares. En más de un caso, los de San Juan Evangelista, por ser el Patrón de los Impresores, los dedicados a la muerte de la Reina Ma Luisa de Borbón, por la importancia cívica del fallecimiento, etc., pensamos que el orgullo profesional de los talleres estaba por encima de los tiempos de confección de la obra y del número de ejemplares impresos. Uno de los carteles [no 19] incluye una «Carta de la Hermandad de Nuestra Señora de Gracia y Socorro, sita en la Parroquial del Señor San Juan desta Villa de Madrid», con instrucciones al pie sobre las obligaciones de los Hermanos, lo que parece señalar claramente su función informativa y una tirada (quizá) reservada sólo para su uso comunitario, así como el espacio reservado para insertar el nombre del Hermano,

31. Hay reproducción facsímile de Víctor Infantes, Poesía matemática (Un cartel poético para el Rey), Mataró, Vèrtex, 1996. 
y de su mujer, como documento acreditativo de su pertenencia, aunque ello no sea obstáculo para que esa Carta este escrita en décimas. En otro caso [ $\mathrm{n}^{\circ} 29$ ] se indica la pie la posibilidad de interpretar el cartel como un regalo a quien cumpla determinados requisitos piadosos: «Danse de limosna, con obligación del que lo recibiere [parece que el plural y el neutro obligan], visite vna vez los cinco Altares por las Almas del Purgatorio, o [rece] vn tercio de Rosario» ${ }^{32}$; igualmente parece deducirse de otro testimonio donde se indica: «[...] Y también las Saetas Espirituales, que van cantando por las calles, en las Processiones que hazen sus Missiones, las quales da de lismosna impresas, en un pliego de papel a lo ancho, para que las fixen en las partes públicas, y las lean todos, y sepan lo que han de hazer» ${ }^{33}$.

Por último, nos intriga, y nos sigue intrigando, el ceremonial de su lectura. Muchos de ellos se conciben como un ornamento (tipo)gráfico que encierra las formas poéticas y prima entonces la visualidad frente al contenido literario, es decir, que el artificio icónico se impone a la planimetría textual; mientras que otros son una simple traslación del tamaño de la página normativa de un libro, con una composición a línea tirada -en algún caso como prosa corrida- donde hay que averiguar la presencia de la estrofa poética, porque la voz textual se ha escondido entre la tipografía y quizá, también, en el subconsciente del autor. Hay carteles de vida premeditadamente efímera, creados para la celebración (y el recuerdo del instante) de un acontecimiento: fiestas, muertes, celebraciones y demás etcéteras de las ceremonias sociales; mientras que otros, de temas intemporales y de insensible cronología, parecen pensados para una cierta permanencia, especialmente los de motivos religiosos, morales y devotos. En el caso de dos de las obras del canario Diego Ramos del Castillo, las Quintilla a la Santa Rosa de Santa María [ ${ }^{\circ}$ 43] y unas Redondillas a la Concepción de la Virgen [no 45], se especifica que se cantaron; en el dedicado a San Nicolás de Bari [ ${ }^{\circ}$ 17], incluye al pie los textos de la "Antiphona» y el «Oremus»; en los Gozos de Nuestra Señora de la Merced [no 34] se añade al final la coda de la letanía ( $O r a$ pro nobis Sancta Maria de Mercede» «Vt digni efficiamur promissionibus Christi»)

32. El plural inicial del verbo podría interpretarse como referido a las Dézimas [...] y Saetas del título y contenido de la obra, pero el neutro posterior sólo es posible interpretarlo como que lo que se da es el propio cartel; si es así, como creemos, entonces la tercera persona hace alusión a los 'carteles' como plural colectivo.

33. En Instrucciones predicables, y morales, no comunes, que deben saber los Padres Predicadores, y Confessores principiantes, y en especial los Missioneros Apostólicos. Por el Padre Fray Joseph Gavarri, Predicador Apostólico, de la Religión de nuestro Seráfico Padre San Francisco, hijo de la Santa Provincia de Aragón. Van añadidos en esta quarta Impressión dos Sermones del mismo Autor [...], Madrid, Antonio González de Reyes, 1679, p. 122. 
y el «Oremus»; en Los claveles y rosas [ no 35] se menciona metafóricamente al final que «en vez de Serafines, assistirán armoniosos coros de la Santísima Trinidad de esta esclarecida Villa» y en las Dézimas, en donde resumidos están los sermones, que predican en sus Missiones por toda España, con orden de su Santidad, los Padres Predicadores Apostólicos [no 29], se incluyen las (que creemos) «Saetas Espirituales, que van cantando por las calles en las Procesiones que hazen en sus Misiones»; lo que supone pensar que, en al menos en estas ocasiones, el cartel sirve (además) de partitura textual para una función melódica o recitativa. Un caso explícito de difusión para el uso personal de la lectura del cartel se señala en uno de los que incluye un laberinto [no 18 ], donde el sentido que tiene «en todas partes [...] se lo dará mejor la destreza del Lector con la ayrosa pronunciación", aunque recuerda también que con la "puntual Ortografía». Quizá los primeros se difunden (masivamente), fijándolos ${ }^{34}$ en los espacios públicos: muros, paredes, lienzos y puertas de edificios e iglesias; los segundos, a cambio, se mantienen pegados en atrios, accesos e interiores eclesiásticos, como uso privado de ciertas hermandades y cofradías. Aparte queda el lector (comprador) de un ejemplar para su decoración (o su lectura) personal. [Un caso aparte, verdaderamente singular, que no incluimos en nuestro "Inventario», es el de la Navegación para el Cielo [Barcelona, Josep Llopis, 1688], también conocida como la Carta del Cartujo ("A todo mortal escribe / Aquesta carta vn Cartujo»), pues aunque su tamaño es de una hoja en doble folio ( $320 \times 425 \mathrm{~mm})$, está impreso para ser leído -iy usado!- con un plegado que lo deja reducido a 71 x $80 \mathrm{~mm}$; por tanto, aunque técnicamente sea un cartel, su verdadera condición editorial, como juego gráfico/textual que se va descubriendo a medida que se abre, es muy distinta ${ }^{35}$.] Escenografías distintas para visiones diferentes de su existen-

34. El trabajo de Rosario Consuelo Gonzalo García, «El ceremonial barroco y la poesía mural: más ejemplos de literatura efímera», en $\mathrm{M}^{a}$ Cruz García de Enterria y Alicia Cordón Mesa, Actas del IV Congreso Internacional de la Asociación Internacional Siglo de Oro (AISO) (Alcalá de Henares, 22-27 de julio de 1996), Alcalá de Henares, Universidad de Alcalá de Henares, 1998, t. I, p. 751-762, insiste, acertadamente y con ejemplos, en esta característica fundamental de la fijación pública del cartel, en particular, p. 752-753.

35. Vid. edición facsímile de la princeps (Barcelona, Joseph Llopis, 1688), con «Billetes» de José A. García y Néstor Costa, Madrid, Ediciones de la Imprenta/Memoria Hispánica, 2010; mientras: Jean-François Botrel, «Sur les usages de l'imprimé. La Navegación para el cielo ou le jeu du Chartreux», en Michel Moner y Jean-Pierre Clément, Hommage des hispanistas français à Henry Boneville, Tours, Societé des Hispanistes Francáis de l'Enseignement Supérieur, 1966, p. 59-74; Esther Galindo Blasco, «Esfuerzo y desapego en la Navegación para el cielo. Un "pasatiempo religioso" del siglo XVIII", Scripta Nova. Revista Electrónica de Geografía y Ciencias Sociales, nº VI, 119 (20) (2002) y José A. Ortiz García, «Entre novísimos y cartujos. 
cia colectiva. Lógicamente, sus lecturas son divergentes, pero en ambos casos estamos hablando de una lectura pública de las obras -silenciosa personal, pero también en ciertas ocasiones en voz alta y compartida-, y no nos cabe la menor duda de su sustracción para la lectura propia lejos del bullicio (o del silencio) de la pared donde estaban pegados.

Dicho lo necesario sobre su existencia editorial, queda conocer la materia de sus contenidos, en esta época de calígine literaria que anticipa el Siglo de las Luces.

En cuanto a la materia de los carteles, es inevitable cierta impresión de terreno movedizo. Estos impresos en doble folio, de frágil supervivencia y en buena medida procedentes de fondos de cierta concentración geográfica y situacional, han ido mostrando, conforme avanzaba el cuentagotas de su localización, decantaciones temáticas y proporciones relativas bastante variables. El resultado es un panorama desigual: en algunos sectores, de notable homogeneidad e incluso reiteración; en otros, con una casuística más compleja, que hace temer posibles discrepancias tipológicas de futuros «hallazgos». Y es que salta a la vista que el doble folio reduce su espectro temático con respecto al cartel en folio, asimismo efímero, pero más barato y manejable, y por añadidura más apto para eludir las incomodidades de su conservación.

Para introducirnos en su tipología temática, puede valernos la convencional dicotomía entre poesía religiosa y poesía profana, no siempre nítida en una sociedad tan proclive a aunar intereses políticos y religiosos, pero por lo general bien definida en estos carteles, quizás en parte por su inherente limitación textual y contextual. Como se verá, más allá de lo temático, tal dicotomía nos adentra en un panorama notablemente disimétrico.

La poesía profana queda reducida a la llamada "poesía de circunstancias". Y nada extrañaría esto, dada la usual vocación del cartel por su lectura en el espacio público, si no fuera porque discrepa en buena medida de lo que ocurre con la temática religiosa, y porque la restricción es aún mayor: en realidad, de entre el cajón de sastre de la poesía ocasional, estos carteles no escogen más que hechos de significación monárquica. Vayamos a las cifras. De los cincuenta y dos carteles manejados solo diez escapan al argumento religioso; de ellos, dos atańen al nacimiento del príncipe Felipe Próspero en 1657 [ $\mathrm{n}^{\circ} 30$ y no 36]; otro alude a un hecho también esperanzador para la sucesión dinástica, las capitulaciones matrimoniales de Carlos II y Mariana de Neoburg, en 1690 [ $\mathrm{n}^{\circ}$ 40]; para las defunciones, en cambio, el corpus se

La cultura gráfica catalana en torno a la muerte», en Actas del VII Congreso Internacional de la Sociedad Española de Emblemática (Pamplona, 2009), en prensa. 
muestra más generoso: siete carteles de distribución muy desigual, seis en honor de María Luisa de Borbón (†1689) [ $n^{\circ} 1$, no 23, no 25, no 41, no 51 y $n^{\circ}$ 52], solo uno para Carlos II $(\dagger 1700)$ [no 21]. Por el contrario, para este período, ningún panegírico nobiliario, ninguna victoria militar ni acontecimiento de la nobleza nos ha salido al encuentro en este gran formato, aunque no falten en carteles en folio.

La reducción temática no es el único denominador común. Su generalizada apuesta por artificios de la poesía visual insinúa una estrecha relación entre el doble folio y las necesidades espaciales de varias composiciones, aunque no siempre parezca haber sido inevitable ese formato. Por lo demás, destaca el escasísimo porcentaje de anonimia, aunque es difícil calibrar el grado de incidencia de varios factores. Cabría pensar en el orgullo autorial anejo a esta adhesión pública; una actitud que, según el caso, podría estar ligada a aspiraciones socio-profesionales personales, sobre todo en el ámbito de la Corte. Con todo, ni el tema ni el contexto cortesano acaban de explicar ese destierro de la anonimia, que por el contrario menudea en otros impresos madrileńos de igual tema con poemas más convencionales, formal y editorialmente. No debe descartarse, pues, que ese orgullo autorial guarde cierta relación aquí con la exhibición de ingenio, y quizás, según los casos, con las condiciones precisas que dieron lugar a estas composiciones. Sin embargo, frente a los frecuentes encabezamientos explícitos entre las páginas de libros y pliegos, estos carteles no suelen indicar si sus poemas proceden de alguna iniciativa extrapersonal, como por ejemplo alguna justa o academia; al fin y al cabo, salvo casos de constatada comercialización, la inmediatez contextual del cartel, a diferencia del impreso de recepción diferida, en teoría haría innecesario consignar esas circunstancias, aunque tal explicación deje hilos sueltos, si se considera la indicación de dedicatarios en algunos carteles. Son otros datos sí explicitados, pero sobre todo la mera recurrencia en un tema, o a veces fuentes externas, los que traslucen empeños colectivos en varios de ellos.

El conjunto más homogéneo de este grupo lo forman seis carteles por el fallecimiento de la reina María Luisa de Orleans (o de Borbón). Su singularidad no oculta su parentesco con toda una línea de poesía áulica en torno a Carlos II, que no solo se plasma en algún volumen académico, sino también en numerosos pliegos u hojas sueltas de filiación menos rastreable, a propósito de sucesos tan diversos como el devoto gesto del monarca de ceder su coche a un sacerdote con el viático (1685), la muerte de la reina (1689), el recibimiento de la nueva consorte (1690) o la preocupante enfermedad del rey $(1696)^{36}$.

36. Tal parentesco se traslada a veces también a su conservación conjunta. Valga de ejemplo 
Entre las secuelas poéticas de la muerte de María Luisa de Borbón, puede destacarse, con su marchamo cortesano, los Cantos fúnebres de los Cisnes de Manzanares, una colección de ochenta y cuatro folios que, aun incluyendo varios poemas con claras relaciones entre sí, muestra una conformación editorial deslavazada ${ }^{37}$. Precisamente su disposición inorgánica y su frecuente encuadernación con piezas análogas han hecho que se les haya atribuido uno de nuestros carteles [ $\left.\mathrm{n}^{\mathrm{o}} 23\right]^{38}$, y si de proximidad con ellos se trata, cabe añadir el parentesco, por autor o recursos formales, entre varios de estos y algunos poemas del libro ${ }^{39}$. Merece citarse el llamamiento que desde la portada hace el librero Sebastián de Armendáriz, "que los publica, y con todo rendimiento pide a los Ingenios ausentes acompañen en tan debido y justo sentimiento a los nuestros con sus cantos, para que por medio de la Estampa sus nombres queden vinculados a la Fama, seguros de que en ningún siglo los sudores de la prensa sean más justificados, ni más bien empleados y recibidos de la común aceptación que en el presente» ${ }^{40}$. Fuera por los sudores del propio Armendáriz, hábil explotador editorial de noticias, o por los de algún otro ${ }^{41}$, lo cierto es que más de una veintena de pliegos dan fe del menudeo poético desatado.

el volumen 9/3550 de la Real Academia de la Historia, donde, junto con otros temas, como la muerte del Duque de Béjar en el asedio de Buda (1686) o, de manera menos recurrente, los fallecimientos de la reina madre (1696) y de Carlos II (1700), se recogen numerosos impresos poéticos y algunos manuscritos sobre la mayoría de los sucesos citados.

37. Cantos fúnebres de los cisnes de Manzanares, a la temprana muerte de su mayor reina doña María Luisa de Borbón nuestra Señora, que goza de Dios, [Madrid], Sebastián de Armendáriz, [1686]. Con una numeración corrida, que, aparte de varios errores en la correlación, mezcla paginación y foliación, el impreso presenta varias portadillas que seccionan la colección en segundos, terceros y cuartos "cantos fúnebres».

38. Así en José Simón Díaz, Bibliografía de la Literatura Hispánica, vol. VII, Madrid, CSIC, 1967, no 4274, y en Catálogo Colectivo del Patrimonio Bibliográfico Español (CCPB0000347434). En realidad, el cartel sólo aparece, en ambigua posición final, en el ejemplar BNE R/2634, que a continuación reúne otros impresos poéticos sobre el mismo tema, independientes de los Cantos fúnebres.

39. Del Vizconde de San Miguel y de Otero, de quien también se conserva un cartel [ $n^{\circ} 52$ ], se recoge en la colección un Soneto en laberinto (f. 41v). A eso habría que añadir la presencia de varios poemas acrósticos (f. 42v [sic] y f. 56v, p. 69, y f. 90r).

40. El llamamiento de la portada se reproduce literalmente en las portadillas de los «segundos» (f. 29r) y «terceros» (f. 48r) «cantos fúnebres».

41. Según Juan Delgado Casado, «no hay seguridad de la posible actividad de Armendáriz como impresor $y$, aunque se mencionan [...] algunas obras que pasan por impresiones suyas, hay que advertir que es muy posible que su papel haya sido solamente el de editor» Diccionario de impresores españoles (siglos XV-XVIII, Madrid, Arco Libros, 1996, vol. I, p. 44). Para su producción, véase José Simón Díaz, Bibliografía de la Literatura Hispánica, vol. VI, Madrid, CSIC, 1973, no 527-553. 
Entre tal efervescencia editorial, los carteles de nuestro corpus, quizás complementarios de otros en tamaño folio ${ }^{42}$, parecen delatar una vertiente e incluso un grado más en la estima de la poesía impresa en este ámbito cortesano, al desbordar con profusión el convencional espacio del libro y la página en cuarto que representan los Cantos fúnebres de Armendáriz. Un ámbito cortesano, con todo, cercenado, pues, entre dedicatarios y autores, se trasluce un fenómeno señalado a veces para las academias del momento: el protagonismo, no de la alta nobleza titulada, sino de sus estratos medios y profesionales liberales, en este caso -en sospechoso indicio madrileño con independencia del origen de los autores-, cargos, oficiales, y quizás aspirantes, del aparato administrativo del Estado ${ }^{43}$.

A la coincidencia temática de este grupo de carteles se suma también, en su mayoría, una precisa identidad de usos artificiosos y, en varios de ellos, comunes indicios pragmáticos.

De un total de seis, cinco se valen del acróstico. El de menor efectismo visual [ $\left.\mathrm{n}^{\circ} 25\right]$, acude al romance heroico, forma pujante de la poesía celebrativa del momento y uno de los pocos casos, en todo el corpus, de poesía endecasilábica al margen del soneto. El acróstico se forma con las iniciales de cada cuarteta y, pese a la ayuda de pseudoestrofa tan amplia (una letra del acróstico cada cuarenta y cuatro sílabas), no extraña que la extensión del romance no moviera al poeta a mayores complicaciones ingeniosas. Sin embargo, el evidente gusto por la superposición de artificios privilegia el poema breve. En cuatro sonetos [no 23, no 41, no 51, no 52], al acróstico se le suma una disposición radial que subraya la presencia de la misma vocal final en cada verso del poema o, en un caso, de solo los tercetos; curiosamente, aunque redundantes con la secuencia del acróstico, a veces se insertan adornos tipográficos (una cruz en el no 23; una manecilla en el no 41) para marcar el punto de inicio de la lectura. Ni siquiera el soneto que dispone de forma radial sólo los tercetos renuncia a compensar la libertad de los cuartetos con un laberinto que duplica el efecto del acróstico [no 45]. Pese a todo, a veces el efectismo del conjunto se quiebra, al amparo de la común autoría, al rellenarse la página con un soneto más, independiente y sin rasgos artificio$\operatorname{sos}\left[\mathrm{n}^{\circ} 23\right.$ y no 41$]$.

Otro aspecto llama la atención: la indicación de un dedicatario para tan breve muestra poética, y más aún, la elección en tres carteles de la misma

42. M. ${ }^{a}$ Cruz García de Enterría y Julián Martín Abad (dirs.), Catálogo de pliegos sueltos poéticos de la Biblioteca Nacional. Siglo XVII, Madrid, Biblioteca Nacional, 1998, $\mathrm{n}^{\circ}$ 10, $\mathrm{n}^{\circ} 74, \mathrm{n}^{\circ} 750$ y no 911.

43. M. a Soledad Carrasco Urgoiti, "Notas sobre el vejamen de academia en la segunda mitad del siglo XVII", Revista Hispánica Moderna, 31, 1965, p. 98 y 108. 
persona, don Manuel García de Bustamante, también él cultivador ocasional de poesía [ $\left.n^{\circ} 23, n^{\circ} 41, n^{\circ} 52\right]^{44}$. Por desgracia, a falta de más datos, el gesto resulta de ambivalente interpretación: si de un lado refuerza la idea de una iniciativa colectiva, quizás una academia, como también sugieren las coincidencias compositivas y de formato, de otro hace pensar, por la propia explicitud, en una esperada recepción ajena al cómplice conocimiento entre miembros de un mismo círculo.

Completa este conjunto fúnebre una composición de distinto artificio: un laberinto retrógrado, de los llamados "cúbicos»" ${ }^{45}$, donde se lee en varias direcciones un pareado asonante que resulta ser un palíndromo ( $\mathrm{A} \mathrm{NO}$ ROCIAR AROMAS ES AMOR ARA Y CORONA») [no 1]. De nuevo, el efecto visual e ingenioso es lo más llamativo, pero otros versos merecen atención. Primero, una redondilla que guía al receptor, desvelando la misión de un indicador tipográfico, el color rojo de la letra que inicia cada enunciado; unos versos, pues, equiparables a las marcas ya comentadas en los sonetos de disposición radial, aunque más explícitos por su carácter declarativo:

\section{Con la A roxa que empieces, Por recinto, centro, y lado, Hallarás el Retrogrado Mil menos quarenta vezes.}

Como se seguirá viendo en otros casos, tal apoyo es síntoma claro de la vacilación que en su difusión plantea esta poesía artificiosa: el dilema entre el desafío al ingenio del receptor y el prurito del autor en ostentar el suyo, lo

44. Intervino en la Academia que se celebró en día de Pasqua de Reyes, siendo presidente don Melchor Fernández de León, Secretario don Francisco de Barrio, y fiscal don Manuel García de Bustamante. Año de M.DC.LXX.IIII., s. 1., s. i., 1674. Antes se publicaron en Nápoles varias composiciones suyas: Engaños desengañados a la luz de la verdad. Poesías sacras, misticas, morales y fúnebres, escritas con la clara tinta del santo desengaño por Gaspar Alonso de Valeria aragonés. Añádense también algunas otras, que estándose imprimiendo las sobredichas, llegaron a manos del impresor, y ha sabido que son de don Manuel García de Bustamante, Secretario de Estado y Guerra del Excelentíssimo Señor Marqués de los Vélez, Virrey y Capitán General de este Reyno de Nápoles, Nápoles, Carlos Porsile, 1681; en el ejemplar visto (BNE R/8716) una nota manuscrita en portada explicita: «Son diez las de Bustamante»; aparecen entremezcladas con las del autor principal. Véase, además, José Simón Díaz, Bibliografía de la Literatura Hispánica, 1972, vol. X, no 4280-4283.

45. «Una composición de letras con tal unidad eslavonadas, que empeçando por la primera letra del verso, se lee por todas partes. Assí lo explica Paschasio [In ingeniosa poesia], que agudíssimamente trata de los Poemas Cúbicos, y de su ingeniosa multiformidad, que a veces se componen quadrados; otras, ochavados; otras, redondos, u de otras figuras, que los poetas pueden idear» (Juan Díaz Rengifo, Arte poética española, en la versión ampliada de José Vicens, Barcelona, José Texidó, 1703, p. 183). 
cual reclama, más allá de la admiración visual, la comprensión del procedimiento y del texto; no es raro, pues, que la balanza soliera inclinarse hacia la adición de textos explicativos, a veces también en verso. En la parte inferior del cartel, el segundo poema que acompańa el laberinto remite por fin a su contenido ocasional. Tras el palíndromo, enigmático en su relación con la muerte de la reina, dos quintillas, casi a modo de subscriptio emblemática, y en un género de prevalencia ingeniosa, la glosa, intentan sortear el riesgo del artificio vacío de mensaje; cuestión aparte es que lo consigan asociando, de modo no muy convincente, los aromas del pareado con una fénix-reina que revive en la vida eterna, y el «amor, ara y corona» con el sentimiento del rey.

Fuera de este fúnebre acontecimiento, los demás carteles civiles localizados muestran mayor dispersión de ocasiones y de usos artificiosos. En uno alusivo a la máscara por el recibimiento de Mariana de Neoburg [n 40], de José de Ogazón Angulo, uno de los autores que escribieron a la muerte de María Luisa de Borbón, el acróstico ("AL SOL D MARIA ANA»), ya del todo necesitado de distinción tipográfica, se forma no al inicio, sino en el interior de los versos; su enunciado exhibe - de nuevo con realce gráfico- la particularidad de empezar y acabar con A, vocal con la que también inicia y concluye cada verso. En definitiva, pues, el poema no hace sino desplegar artificios visuales y compositivos de análoga naturaleza a los ya vistos en los sonetos a la anterior reina, si acaso con una mayor pretensión de efecto virtuosista.

En cambio, los otros tres carteles de tema monárquico asumen técnicas distintas. Así, el feliz nacimiento de Felipe Próspero y la lamentada muerte de Carlos II coinciden en originar sendos carteles marcados por la exhibición de un extravagante ingenio alfanumérico.

En el primero [no 36], el teólogo Adriano Modrón afirma haber predicho, meses antes, el nacimiento de un heredero que sobresaldría en Letras y Armas como paladín de la Cristiandad. Tan adulador cuanto incumplido pronóstico se funda en la arcana coincidencia de las mismas ciento sesenta y nueve letras, con distinta combinación, que constituyen tanto el así llamado «argumento", sin rima, alusivo a la reina, como el «anagrama» del vaticinio, vagamente asonantado. De nuevo, ante correspondencia tan poco perceptible en una lectura convencional, se requiere la explicación del artificio del anagrama, a lo que se ańade, abajo, como dedicatoria al valido Luis de Haro, una erudita disertación, salpicada de frecuentes citas bíblicas y alguna clásica, sobre el vínculo simbólico que mantienen los nombres con sus parónimos y anagramas.

En el segundo cartel [ $n^{\circ} 21$ ], el alférez mayor Jerónimo Ares de Vaamonde parte de una compleja serie de equivalencias entre letras y valores numéricos, también de necesaria indicación en el impreso por su asociación completa- 
mente arbitraria. El poema se reduce a una cuarteta de romance que combina el tópico ascético del poder igualador de la muerte con el motivo circunstancial. Y el ingenio de la composición se basa en que el número de días que vivió Carlos II es igual a la suma resultante del valor atribuido a cada letra de la cuarteta. Por lo demás, la aritmética se adereza con citas clásicas y bíblicas sobre la brevedad de la vida y otros tópicos morales, y sobre la idea rectora del «cómputo» de días.

Pese al diferente mecanismo artificioso en sendos carteles, no se ocultan varias coincidencias de fondo: así, la extrema reducción del componente poético en favor de un saber técnico de base combinatoria (matemático o anagramático); el prurito erudito, ausente o, cuando menos, no explicitado en otros carteles civiles; las menciones de los ejercicios profesionales de sendos autores, quizás con asociación implícita al artificio empleado -recuérdese la autorización bíblica del anagrama en el caso del teólogo y el saber matemático como parte de la formación técnica militar del alférez-; y, por supuesto, la transmisión de un conocimiento arcano o presentado como tal.

Por último, en este muestrario artificioso queda por citar un romance mudo por el nacimiento de Felipe Próspero [no 30]. De todo el corpus, es el único cartel de tema profano con vinculación constatada a una justa poética, aunque no es seguro que tal circunstancia figurara en el cartel, que podría estar mutilado en su estado actual ${ }^{46}$. Esta se celebró en Alcalá, y por el volumen recopilatorio de la misma, que afecta no recoger el poema por bien conocido, se sabe que fue presentado en la modalidad de jeroglíficos ${ }^{47}$. Frente a la práctica más extendida del «jeroglífico» en la época, en la que la relación entre imagen y texto se basaba en una operación simbólica o conceptual, el poema mudo, con mecanismo idéntico a nuestros jeroglíficos actuales, jugaba con la cadena fónica resultante de la «lectura» de las imágenes. A la altura

46. Rosario Consuelo Gonzalo García, «Sucesos mayores en impresos menores: El nacimiento del príncipe Felipe Próspero (1657)», Rivista de Filologia e Letterature Ispaniche, II, 1999, p. 137; las citas del cartel se realizan a partir de su reproducción en p. 149.

47. Ibid., p. 138-140. La relación de la justa permite conocer el autor del cartel: fray Diego García. Como dato curioso, también documenta la convivencia de copias manuscritas e impresas entre las aportadas por los participantes para la exposición mural: «Todo el Teatro estuvo adornado con los papeles de las Poesías, todos ermosamente escritos, y muchos impresos, dispuestos y correspondientes todos al Certamen a que correspondían, puesto [sic] sobre los papeles de cada Certamen una tarjeta y en ella unas palabras que lo declaraban» (Francisco Ignacio de Porres, Justa Poética zelebrada por la Universidad de Alcalá Colegio Mayor de S. Ilefonso en el nacimiento del Príncipe de las Españas, Alcalá, María Fernández, 1658, p. 115). Con todo, según señala Rosario Consuelo Gonzalo García, el ejemplar conocido no conserva rastros de haber sido expuesto (art. cit., p. 139). 
de 1658, el procedimiento era conocido en justas, como mínimo, desde hacía décadas ${ }^{48}$, aunque tal vez con anterioridad se limitara a poemas breves, si hay que conceder crédito al autor de este romance, fray Diego García, quien se atribuye la novedad de tal tipo de composición ${ }^{49}$.

Salvo quizás por el romance heroico en honor de María Luisa de Borbón, su contenido poético es el más extenso y discursivo del grupo de carteles civiles. El poema central, aquí solo en viñetas, queda bastante constreñido en sintaxis y léxico por las limitaciones gráficas del artificio elegido, achaque común a tantos de su género. Pero a él acompaña una composición metapoética que da pistas sobre el autor sin desvelar su nombre («El Autor deste Romance, / con ser hombre de más letras / que tiene todo Alcalá, / no quiere valerse dellas»), publicita la venta de la «llave» o transcripción del romance («Las pinturas que dudares, / con legal inteligencia / en el Colegio de Aquino / te las dirán, en la Imprenta») y, sobre todo, ayuda, como en otros carteles otros recursos, a la descodificación del artificio. Al fin y al cabo, pese a su apariencia «natural» y atemporal, lo dibujado requiere una interpretación no solo visual -es decir, identificar qué aparece en cada viñeta- sino también cultural. Y esto último no sólo por algunas ocasionales licencias para llegar a ciertas lecturas, de las que se advierte al potencial "lector» ${ }^{50}$, sino sobre todo por el convencionalismo histórico, anclado en el contexto iconográfico, simbólico y socio-cultural del momento ${ }^{51}$. En todo caso, el hecho de que en

48. Así, por ejemplo, un soneto presentado en la justa celebrada en Granada por la beatificación de San Ignacio, «el qual, aunque mezcladas algunas letras, habla solamente con cifras, o figuras pintadas; es más para ver, que para dezir. [...] Que por estar todo axedrezado con rayas, y estar con figuras y palabras, y cada una en su casilla, parecía muy bien, y se leýa con facilidad" (Relación de la fiesta que en la beatificación del B. P. Ignacio... hizo su Collegio de la Ciudad de Granada, en catorze de Febrero de 1610, Sevilla, Luis Estupinán, 1610, f. 84v-f. $85 \mathrm{v})$.

49. «Agradeced la invención, / si no por grande por nueva, / que todo lo nuevo aplace, y estamos en buena escuela" [ $\left.n^{\circ} 30\right]$.

50. «Pero podrás, si gustares, / porque en ayunas no buelvas, / comerte una letra u otra / y más de quatro no sean. / También se permite que / parte de figuras puestas / en el remate de un verso / al siguiente pasar puedas» [ $\left.\mathrm{n}^{\circ} 30\right]$.

51. En el poema por el nacimiento del príncipe, un pregonero con bocina remite a la representación alegórica de la Fama (v. 8). En otro romance mudo [no 32], se vuelve a acudir a la alegoría, por ejemplo para el término «Fe» y aun las sílabas «fe»/«fes» (una mujer con un cáliz en su mano derecha y una cruz en la izquierda, casi al modo como la describe Cesare Ripa en su célebre Iconología), mientras que la iconografía al uso y la realidad social permiten identificar respectivamente los términos "clara» (Santa Clara con la custodia) y "grande» (un caballero con el Toisón de Oro), aunque en este último caso las anejas «Notas a este retórico romance mudo" guían la lectura: «Dos Fees junto a una teja / del segundo verso es parte, / donde uno está con Tusón, / insignia que le haze Grande.» 
impreso aparte se publicara una «llave», que en dos columnas emparejaba la transliteración de las imágenes y el romance resultante ${ }^{52}$, no solo ilustra la popularidad del poema y la curiosidad intelectual suscitada sobre su «textualidad», sino también la insuficiencia de la ayuda proporcionada en el cartel.

Si pasamos a los carteles de tema religioso, pese a algún punto de contacto, el panorama es muy distinto, empezando por su número, que cuadriplica el de carteles de asunto civil. Frente a la reducción temática de estos, la materia religiosa genera una casuística más amplia, y la poesía ocasional, aun con notable protagonismo, no la monopoliza. Eso no implica que tras poemas sin marcas circunstanciales no pueda esconderse algún desencadenante. Sin embargo, tanto la poesía ligada a las figuras de culto más comunes como, sobre todo, la meditativo-penitencial, evidencian, al margen de posibles estímulos ocasionales, una notable capacidad para generar textos sobre los que el lector (casi es decir: el devoto) puede volver de forma atemporal. Puede, y debe, porque otro aspecto destacable, como en otros textos religiosos, es la estima de una lectura reiterada, que se hace hábito, y que debió de hallar cobijo, incluso en este formato del cartel, en el espacio privado.

Por lo demás, en dualismo tan arraigado en la concepción religiosa, la relevancia de la materia prevalece sobre lo estético. Esta última faceta solo parece estar cuidada en la medida en que una precisa disposición editorial (por ejemplo, el aspecto de retablo del Sumario de vida cristiana, escala espiritual y guía de perfección [ ${ }^{\circ}$ 49]) o, más frecuentemente, el mero uso de algún grabado -por lo general de convencional referencia piadosa o meditativa- pudieran activar la piedad o, aun antes, al primer vistazo, la curiosidad del potencial lector [ $\mathrm{n}^{\circ} 4, \mathrm{n}^{\circ} 10, \mathrm{n}^{\circ} 16, \mathrm{n}^{\circ} 17, \mathrm{n}^{\circ} 19, \mathrm{n}^{\circ} 33$ y no 50 ]. Incluso debió de concebirse esa capacidad de atracción como inherente al formato del cartel y a sus contextos de exposición, al margen de su ornato, si nos dejamos llevar por los versos iniciales de uno que, de hecho, no exhibe más sensibilidad por lo visual que una desahogada disposición del texto: «Quando tu curiosidad / te ha de obligar a leer / lo quisiera yo bolver / en eficaz voluntad» [no 28]. Esa prevalencia del contenido sólo halla, en nuestro corpus, dos notables excepciones: la extremada vistosidad tipográfica de varios carteles dedicados a San Juan Evangelista y algunas raras muestras de poesía visual.

El primer caso es cuantitativa y estéticamente destacado. Se trata de los carteles relacionados con la fiesta patronal de los impresores, la de San Juan ante portam Latinam. La costumbre de editar elaborados carteles para la

52. La «llave», en tamaño folio e igualmente impresa a una sola cara, está también reproducida en Rosario Consuelo Gonzalo García, art. cit., p. 150. 
ocasión, más amplia temporal y geográficamente, aparece muy localizada en nuestro corpus: de los trece carteles incluidos, cinco pertenecen a la fiesta de 1683 [n $\mathrm{n}^{\circ}, \mathrm{n}^{\circ} 5, \mathrm{n}^{\circ} 7, \mathrm{n}^{\circ} 13$ y no 47], cuatro a la de 1689 [no $6, \mathrm{n}^{\circ}$ 9, no 11 y $\left.n^{\circ} 15\right]$, ambas en Madrid, y hay tres sin pie de imprenta, aunque quizás relacionados con los anteriores [no 3, no 14 y no 24]; sólo uno de los localizados procede declaradamente de otro centro impresor, Zaragoza (1694) [no 12], aunque también se tienen noticias de carteles sevillanos de 1674, al parecer en tamaño folio ${ }^{53}$.

El cuidado editorial parece empeño común en todos, aunque en unos casos se trate de un grado solo ligeramente superior a la media en el cartel devocional en cuanto al uso de orlas y grabados [no $2, n^{\circ} 3, n^{\circ} 13, n^{\circ} 14$, $\left.n^{\circ} 15 y^{\circ} 24\right]$, en otros se juegue vistosamente con adornos tipográficos para simular hornacinas y altares que enmarcan el poema y la imagen del santo [no $5, n^{\circ} 9$ y no 11$]$, y en unos pocos se realicen composiciones más imaginativas y de gran virtuosismo impresor [ $n^{\circ} 6, n^{\circ} 7, n^{\circ} 12$ y no 47]. No obstante, frente a lo que ocurre en los carteles de poesía civil, se trata de un artificio meramente tipográfico, ligado al pundonor profesional, individual o colectivo. Así lo refleja Alonso Víctor de Paredes, en su Institución y origen del Arte de la Imprenta, de hacia 1680, que permite remontar la costumbre a fechas mucho más tempranas que las que documentan los carteles localizados:

En lo que pertenece a las Poesias, ò Romances que se hazen para la Fiesta del señor SAN IVAN Ante Portam Latinam, nuestro Glorioso Patron, no tengo, ni se me ofrece nada que dezir: porque esso cada vno los dispone en la forma que mejor le parece, y conforme à su buen zelo, y asseguro ingenuamente, que todos los que he visto de casi veinte ańos à esta parte, no he tenido en que hazer reparo de consideracion, porque todos procuran excederse a si mismos, y a mí me ha dado sumo consuelo el ver en esta parte llegado tan à lo sumo de la perfeccion nuestra Arte ${ }^{54}$.

Por el contrario, lo experimental no afecta al poema. A lo más que se llega, alguna vez, es a enlazar algunos de sus conceptos o metáforas con la figuración visual (San Juan como cáliz [ $\left.n^{\circ} 12\right]$, custodia [no 7], fuente

53. Santiago Montoto, Impresos sevillanos, Madrid, CSIC, 1948, p. 76-77. Véase el trabajo de Víctor Infantes, «La santidad tipográfica en la España del Siglo de Oro. Las honras poéticas a San Juan Evangelista, Patrón de los Impresores», ya citado.

54. Alonso Víctor de Paredes, Institución y origen del Arte de la Imprenta y reglas generales para los componedores, ed. y pról. de Jaime Moll, noticia editorial de Víctor Infantes, op. cit., f. $40 \mathrm{v}$. 
[no 47]...). Pero, en todo caso, los textos no salen del convencionalismo devoto, ya sea con una neutra expresión cuasi-oracional, ya sea en una más lúdica línea de conceptismo religioso.

La segunda excepción referida delata nuevas discordancias con los carteles de tema civil, ya que los dedicados a poesía religiosa muestran una escasísima aceptación de la poesía visual, que, además, o queda reducida a algún contexto festivo preciso o reorienta su sentido hacia cierto didactismo. De hecho, solo cuatro de los cuarenta y dos carteles religiosos manejados entran en este ámbito, con tres procedimientos: el poema mudo, el laberinto y, con menor efectismo artificioso, el acróstico.

Se conoce un cartel completo con un romance mudo dedicado a la Inmaculada Concepción [n $\left.{ }^{\circ} 32\right]$ y quizás habría que añadir otro, del mismo tema, del que se conserva la llave, sin las imágenes, en tamaño folio aunque, en una de sus ediciones, con indicios de mutilación que tal vez remitan a un doble folio original ${ }^{55}$. Ambos remiten a los festejos de 1662 con motivo de una bula de Alejandro VII que consolidaba el avance de la doctrina inmaculista; su contexto inmediato, en cambio, no está tan claro. El primero, compuesto e impreso en Madrid, incluye, junto a las vińetas, unas «Notas» que, de nuevo, ayudan a descodificar las imágenes. De sus últimos versos parece desprenderse un contexto competitivo -no necesariamente configurado como justa poética, en tanto que dirigido al receptor, aunque tampoco pueda excluirse-, donde «el que todo lo entendiere, / sin la explicación de nadie, / en premio puede tomar, / de las que tiene delante, I una alhaja la mejor, / no tocando a los boçales, / porque esse premio se queda, / para los que se les haze / todo este romance mudo / lleno de dificultades». Aun así, a la derecha puede leerse el romance, que, por cierto, dedica varias cuartetas a la exaltación monárquica, rara muestra en estos carteles

55. Se conocen dos ediciones de esta llave, ambas en la Real Academia de la Historia. Se halla una en el volumen 9/3576, cuyo índice inicial parece evidenciar la originaria inclusión de la lámina de vińetas («Romance mudo a la Concepción con su llave»); actualmente falta, según la foliación antigua, el f. 207, donde podría haber estado la versión «muda» del romance: el hecho de que esa hoja siga a la llave parece sugerir que no formaban un cartel, o, al menos, que no llegaron al compilador como tal. No obstante, en el volumen 9/56, la encuadernación de la llave deja sospechar una mutilación en su parte izquierda, que podría corresponder a una presentación conjunta con las viñetas en tamaño de doble folio. Se diferencia del otro impreso, aparte de por cuestiones tipográficas -entre ellas las orlas utilizadas-, por el orden en que aparecen las dos versiones del poema (el del volumen 9/3576 aclara bajo el título: «En la primera columna se lee corriente, y en la segunda se ponen las figuras con distinción»; el del volumen 9/56, en orden invertido, indica simplemente «Pintado» y «Leýdo» sobre cada columna), y en que en este segundo impreso las cuartetas de romance van numeradas, posiblemente para facilitar la confrontación simultánea con las vińetas; el texto no varía. 
religiosos, pero habitual en ciertos contextos festivos, como, entre otros, los de las justas. Del otro hipotético cartel, la llave conservada apenas da más indicio que una posible ubicación sevillana ${ }^{56}$, y al igual que la del romance por el nacimiento del príncipe, recuerda la problemática descodificación de las imágenes, con una doble disposición paralela, que confronta la lectura normal y la secuencia creada por las viñetas.

Por su parte, el laberinto aparece en dos modalidades. Un «laberinto cúbico» de figura cuadrada, análogo al ya visto en honor de María Luisa de Borbón, articula un cartel de contenido meditativo-penitencial [ $n^{\circ} 46$ ]. Pese al común mecanismo, al comparar los dos impresos las diferentes prioridades resultan significativas. La misma composición de la página sugiere, en el cartel religioso, un protagonismo menor del laberinto; las glosas, más destacadas en su disposición y tamaño de letra que en el otro caso, desarrollan y enriquecen, con mayor coherencia y eficacia que en el fúnebre, el mensaje del pareado que da pie a la construcción laberíntica. Y este, frente al palíndromo del otro cartel, no comporta ningún llamativo artificio, sino una formulación clara, sucinta, con plena autonomía de sentido, y por todo ello, mnemotécnica, del mensaje que se quiere inculcar: "Número tiene el pecar, / no le llegues a llenar». De hecho, incluso la redondilla que arriba, también aquí, desvela el punto de inicio para la lectura (la ' $N$ ' central) remite, con premeditada ambivalencia, no tanto a la mera y virtuosista repetición (aquellas «mil menos cuarenta veces» del cartel dedicado a María Luisa de Borbón) como a la relevancia de su mensaje: «hallarás, aunque sucinto, / lo mucho que en sí contiene».

El otro laberinto de tema religioso, en alabanza del Santísimo Sacramento, no se basa en la reiteración sino en la multiplicación del texto a partir de un número limitado de «piezas» de variable combinación: los ciento veinticinco versos de veinticinco quintillas [no 18]. Se trata de lo que Rengifo llama «laberinto de versos enteros» ${ }^{57}$. Como se explica en la parte inferior del cartel, el ingenio constructivo de las quintillas

casi las multiplica en infinito. Léense sueltas hasta el fin; y subiendo desde él hasta el principio, comenzando cada Quintilla por el quinto verso. Léense por cada uno de los dos lados hasta el contrario, tomando de cada columna el verso, que le corresponde enfrente.

56. A tal referente apuntan los versos siguientes: «Cantárosla, Fieles, toca / a la Iglesia a la Giralda, / y ella con pasmo no oýdo / retumbava las Campanas» (puede verse reproducción de la llave en Rosario Consuelo Gonzalo García, art. cit., p. 154).

57. Juan Díaz Rengifo, Arte poética española [Madrid, Juan de la Cuesta, 1606], ed. facs. de Antonio Martí Alanís, Madrid, Ministerio de Educación y Ciencia, 1977, p. 95. 
Léense desde cada una de las quatro esquinas hasta la opuesta, y bolviendo al contrario. Léense por ambos lados en triángulo, en harpón. Y finalmente se leen desde qualquiera verso, saltando abaxo, o arriba, o a los lados; de suerte, que en todas partes se hallará consonancia, y sentido.

Con todo, la multiplicación es engañosa, pues el arte combinatoria no cambia, en el fondo, el mensaje; así, tras cierto componente lúdico, lo que se esconde no es sino una variante de la clásica práctica devota de la lectura reiterada de un texto, que aquí se disfraza de multitud de textos de idéntico sentido.

Por lo demás, casi anecdótico dentro del corpus de tema religioso localizado resulta el uso del acróstico en uno de los carteles barceloneses dedicados a Santo Tomás de Aquino [no 16]. Recoge éste unas redondillas de convencional contenido encomiástico, análogo al de otros carteles del mismo tema, ciudad y año, en distintos formatos ${ }^{58}$, las cuales simplemente quedan forzadas en su letra inicial para formar el acróstico. La relativa brevedad y sencillez de éste («THOMAS DE AQVINO») y la simplicidad también del metro elegido contribuyen a que, dentro de su inherente artificiosidad, el procedimiento no llegue a los niveles de recargamiento vistos en los carteles de tema áulico.

Junto a este escaso interés por la poesía visual, otro síntoma del valor secundario de los aspectos estéticos es el frecuente abigarramiento textual del cartel religioso. Si en los ejemplos de tema civil no era raro encontrar una disposición desahogada, con solo uno o dos sonetos, aquí se tiende a cubrir extensas zonas de la página: a veces con un poema relativamente amplio, un romance o una serie de décimas, en varias columnas [no 8, no 50 y no 28]; a veces acumulando formas breves, sin distinción tipográfica, como los tercetillos y pareados de las «saetas espirituales que van cantando [los predicadores franciscanos] por las calles en las procesiones que hacen en sus misiones» [ $\mathrm{n}^{\circ}$ 29], o el cartel con décimas a la Inmaculada Concepción de varios autores [no 27]; otras veces combinando formas breves con otras más discursivas [ $n^{\circ}$ 19]; e incluso en una ocasión, despojando a la poesía de su más común marca visual, la separación versal, para disfrazarse de prosa y aun fundirse

58. En doble folio, véase $\mathrm{n}^{\circ}$ 10; en folio: A lo que el angélico doctor Santo Tomás de Aquino escrivió del Sacramento del Altar. Dézima, Barcelona, Imprenta de Matevat, 1680; Al centro de las virtudes, y abismo de la sabiduría Santo Thomás de Aquino. Romance, Barcelona, Rafael Figueró, 1680; Al más luminoso planeta, quinta essencia de los dotores. Romance, Barcelona, Rafael Figueró, 1680. 
con ella en un cartel a línea tirada que oculta entre sus renglones versos en seguidillas y en forma de romance [ $\left.n^{\circ} 35\right]$.

Hay dos grandes excepciones a esta tendencia. Por una parte, los ya mencionados carteles a San Juan Evangelista, que, al privilegiar la composición tipográfica, a veces reducen su contenido poético. Por otra parte, un pequeño grupo de impresos con poemas de breves estrofas octosilábicas que aparecen orladas por separado [no $37, n^{\circ} 38, n^{\circ} 39$ y no 42]. La semejanza dispositiva y temática de estos últimos con impresos al parecer destinados a ser recortados en pequeñas cédulas, que luego se esparcían en actos festivos o litúrgicos, hacen pensar en ese posible uso ${ }^{59}$; con todo, varios aspectos llevan a no tomar como exclusiva esa hipótesis y a pensar también en un producto conmemorativo: así, elementos tan característicos de una presentación editorial unitaria, como, en algunos de ellos, el encabezamiento corrido a lo largo del doble folio y el pie de imprenta [no 38, 39, 42], alguna referencia a la fiesta en pasado [ $n^{\circ} 42$ ], o incluso varias conexiones interestróficas en los poemas, en principio poco propicias a su disgregación [n 37].

Otro punto divergente entre estos impresos religiosos y los de tema profano es el alto porcentaje de anonimia. Solo nueve carteles religiosos identifican a los autores, aparte de otro que únicamente remite a un encubierto «Esclavo del Santíssimo en su Congregación del Caballero de Gracia», que «dedica» (¿compone?) el laberinto en quintillas [no 18]. Por otra parte, la dedicación del poema a un particular, no rara en los carteles profanos, se reduce aquí a otro de los atípicos poemas artificiosos del grupo, el laberinto cúbico de tema meditativo-penitencial, dedicado a «Don Antonio Pérez de la Puente, Cavallero del Orden de Santiago, del Consejo de Su Magestad, en el Real de Hazienda» [no 46]. Cabe pensar, pues, que los circuitos de autoría y dedicatario, y su entramado personal y socializador, se ven sustancialmente trastocados por las connotaciones asociadas a la práctica y transmisión de este tipo de poesía. Por otros contextos, puede pensarse en la incidencia de valores devotos, de humildad y de indistinción en una conciencia colectiva, valores que de algún modo se intuyen, por ejemplo, en la citada anonimia del esclavo del Santísimo Sacramento. Como en otros aspectos, el mensaje ejerce su hegemonía en detrimento de la autoría; y también lo hace su vocación de asunción colectiva, que se convierte en tradición no necesitada de una «autoridad» textual. Aunque, por motivos de control, la despreocupación autorial no es común en toda la producción religiosa, aquí la ortodoxia

59. Un ejemplo explícito al respecto, pero en tamaño folio, puede verse en el impreso Poesias que se esparcieron en la fiesta del juramento de la Concepción de N. Señora, que hizo el Colegio de S. Hermenegildo de la Compañia de Jesús, [s. 1, s. i., s. a., pero Sevilla, 1653]. 
no viene avalada por el autor, sino por la autorización legal que conlleva esa «licencia» o "corrección de la Santa Madre Iglesia» que muchos carteles se cuidan de hacer constar [no $10, n^{\circ} 18, n^{\circ} 20, n^{\circ} 22, n^{\circ} 27, n^{\circ} 32, n^{\circ} 33$, $n^{\circ} 34, n^{\circ} 35, n^{\circ} 43, n^{\circ} 44, n^{\circ} 45 n^{\circ} 50$ ]; o bien, en menor medida, por ciertos contextos de uso, como en sendos impresos con los versos empleados en misiones por España de predicadores franciscanos y jesuitas [no $29^{60}$ y no $26^{61}$.

Con esta tendencia, las escasas indicaciones de autoría parecen apuntar a situaciones particulares, donde pueden hallarse o sospecharse poemas por encargo (como el del Padre Camargo para el gremio de impresores [no 24]), o prácticas colectivas o cuasi-académicas (como las décimas de cinco autores del entorno granadino [ $\left.\mathrm{n}^{\mathrm{o}} 27\right]^{62}$ ), o quizás propósitos personales en la impresión del cartel (como los tres del licenciado Ramos de Castillo, que no

60. Estas «décimas» y «saetas», con variaciones en su número y orden y con ligeras variantes textuales, aparecen recogidas, junto con una versión próxima a las advertencias en prosa que también recoge el cartel, en José Gavarri, Interrogatorio en forma de diálogo... de las preguntas necessarias que deven hazer los PP. Confessores, con las personas que oyen de confessión, las quales hasta oy no se han impresso con este método y claridad. Las mismas servirán para los que desean saber confessarse, con las más singulares noticias que hasta oy se han escrito en lo Moral, adquiridas con la práctica de diez y ocho años de Missiones que ha hecho, Granada, Imprenta Real de Francisco de Ochoa, 1676, f. 122-f. 131r; y del mismo autor, Instrucciones predicables, y morales, no comunes, que deben saber los Padres Predicadores, y Confessores principiantes, y en especial los Missioneros Apostólicos... Van añadidos en esta quarta Impressión dos Sermones del mismo Autor [...], Madrid, Antonio González de Reyes, 1679, f. 111r-f. 112r y 170r y ss. En ambos casos se explicita el marco misionero franciscano.

61. Para la datación del pliego, posterior a 1672, se tiene en cuenta que el cartel menciona al «Venerable P. Fr. Luis de la Puente, de la Compañía de Jesús, Varón esclarecido en virtud, cuya Beatificación se trata ya, por orden de su Santidad». Las prohibiciones para incoar procesos de beatificación hasta que no pasaran cincuenta años del fallecimiento del investigado impidieron hasta ese año la autorización papal mencionada, según el Epitome de la Vida del V. Padre Luis de la Puente, de la Compañia de Jesús, que escrivió el P. Francisco Cachupin, de la misma Compañia. Dispuesto por el Padre Bernardo Sartolo, de la misma Compañia, Pamplona, Imprenta de los Herederos de Martinez, p. 279.

62. Se trata de Juan de Trillo, hermano de Francisco de Trillo y Figueroa, Juan [Antonio] de la Vella, Diego Fernández Solana, Gabriel Martínez [¿¿del Águila?] y Pedro [Alfonso] de la Cueva [y Benavides]. Casi todos ellos dieron muestras reiteradas de sus aficiones poéticas en relaciones de fiestas o sucesos, justas, academias y otras iniciativas colectivas; puede verse al respecto Antonio Gallego Morell, Francisco y Juan de Trillo y Figueroa, Granada, Universidad de Granada, 1950; y, para los autores menos conocidos, sin ánimo de exhaustividad, M. José López-Huertas Pérez, Bibliografía de impresos granadinos de los siglos XVII y XVIII, Granada, Universidad de Granada, 1997, entradas no 1, no 132, n 187, no 207 y no 426 (J. de la Vella); no 194 y no 426 (D. Fernández Solana); no 194 (G. Martínez del Águila); no 1, no 170 y no 207 (P. A. de la Cueva). 
parecen concebidos, con sus detalles circunstanciales formulados en pasado, para los contextos que generaron los poemas [no 43, no 44 y no 45] ${ }^{63}$ ).

No es viable adentrarse aquí en la compleja casuística del entrecruzamiento, sin correspondencia unívoca, entre los diferentes subgrupos temáticos y las variables pragmáticas que se explicitan o se intuyen en estos carteles. Habrá que limitarse a unas notas muy generales.

Bastante homogéneo resulta un grupo de seis carteles de tema meditativopenitencial, en torno a la meditatio mortis, el peligro de condenación eterna, las virtudes del continuo ejercicio de una vida penitente y la necesidad de la confesión. Su aspecto formal ofrece cierta diversidad: desde el extenso escrito en prosa con solo algunos versos detallados entre las devociones propuestas en un cartel jesuita [no 26], al laberinto cúbico [no 46]; desde el abigarramiento de las sentencias cantadas en las misiones franciscanas [no 29], a la más despejada composición en forma de doble página con sendas glosas de dos octavas de larga tradición meditativa [n $\left.\mathrm{n}^{\mathrm{0}} 31\right]^{64}$; pasando también por el ya visto Sumario de la vida cristiana [no 49], o un género clásico de este tipo de poesía, las décimas a la muerte [no 28]. Sin embargo, de la identidad de mensaje e intención se desprenden otros rasgos comunes. El más esencial de todos, su carácter atemporal: aun en los casos en que el contenido del cartel se vincula a una actividad concreta, como la de las misiones, su validez se prolonga más allá de la ocasión que le dio origen. De hecho, solo dos de estos carteles tienen fecha de publicación, y de uno de ellos, con las dos glosas mencionadas, cabe sospechar sea reedición ${ }^{65}$. Vendidos, como a

63. Apenas se tienen datos biográficos de este autor, del que fueron publicados tres autos sacramentales en la colección costeada por Juan Fernández, Autos sacramentales, y al nacimiento de Christo con sus loas, y entremeses. Recogidos de los maiores ingenios de España, Madrid, Antonio Francisco de Zafra, 1675; uno de ellos se conserva también manuscrito (BNE, Ms. 12974(53)). Pueden verse ahora Paula Jiménez Hernández (ed.), Los autos sacramentales del tinerfeño Diego Ramos del Castillo, Santa Cruz de Tenerife, Ediciones Idea, 2009.

64. Véanse abajo notas 65 y 66.

65. El ejemplar localizado se imprimió en Madrid, Imprenta Real, 1652, y aparece encuadernado como cartel, aunque las orlas tipográficas delimitan el espacio a modo de dos hojas de tamaño folio independientes; incluye el rótulo «Parte I» antes de la glosa que aparece a la derecha. Aunque la composición de conjunto tampoco resulta del todo coherente, parece complementario de otro impreso solo localizado en ejemplar publicado en Madrid, por Gregorio Rodríguez, 1649, y, al igual que el de 1652, vendido «enfrente del Colegio de Atocha", aunque en establecimiento de distinta titularidad (Real Academia de la Historia 9/3576(16)). Asimismo encuadernado como cartel, coincide con el de 1652 en el diseńo de conjunto y la igual distribución del espacio en dos hojas autónomas, el grabado de esqueleto con guadańa y, por supuesto, su contenido meditativo-penitencial, con tendencia al uso de la octava y al procedimiento de la glosa. En este caso, la parte izquierda está ocupada por un soneto ("¿Quién eres, hombre, di? Soy tu hechura») y un poema en octavas rotulado $\mathrm{Al}$ 
veces se explicita [no 31 y no 49], o regalados bajo chantaje devoto, aparecen abocados a una circulación y lectura individual. Individual y reiterada, como la que aconsejan los versos de otro cartel: «Un quarto de hora te pido / cada día de atención, / y mi razón de razón / te dexará convencido" [ $\left.\mathrm{n}^{\circ} 28\right]$. Todo ello explica que, de todo el corpus, en una somera búsqueda de testimonios manuscritos, los escasos poemas hallados pertenezcan todos a este grupo ${ }^{66}$.

desengaño del hombre («Si habemos de dar cuenta de la vida»); la de la derecha, por la octava con íncipit «Larga cuenta que dar de tiempo largo», con una glosa precedida del rótulo «Parte II» («Si por obra, palabra o pensamiento»). Aunque la glosa de esta octava no sea la misma que figura en los pliegos con poemas de Lope citados abajo en nota 66 (1613-1629), estos dos impresos de mediados de siglo dan la impresión de remitir a la misma incógnita que plantea el título de Segunda parte del desengaño del hombre de dichos pliegos, de los que, al parecer, no se conoce una Primera parte.

66. La consulta de Pablo Jauralde (dir.), Catálogo de manuscritos de la Biblioteca Nacional con poesía en castellano de los siglos XVI y XVII, Madrid, Arco/Libros, 1998-[2008], puede ilustrar esta focalización de la transmisión manuscrita, con todo no muy abundante aunque delatora de reelaboraciones que traslucen la popularidad de algunos versos o cabezas de glosas. Con respecto al pareado del cartel no 46, el mismo verso inicial («Número tiene el pecar») encabeza una quintilla con glosa en el ms. 6635 BNE, f. 365r-f. 366r. Una de las octavas que dan pie a glosas en el cartel no 31 , la que tiene como íncipit «Oí, palpé, gusté, vi y tuve olfato», se copia sin respetar la correcta separación de los versos y con agregación de otro breve texto al final en el ms. 7741 BNE, f. 263v-f. 264r. También se conserva manuscrita una versión de las saetas de contexto misionero franciscano, identificado en el encabezamiento, en ms. 3926 BNE, f. 170r-f. 171r. Pero, sin duda, el texto más recurrente y reutilizado es la octava con íncipit «Yo, ¿para qué nací? Para salvarme» [no 31]: la casuística de su transmisión recorre la presencia aislada de la octava que sirve de cabeza de glosa (ms. 6620 BNE, p. 251-252), la copia de la misma la glosa recogida en el cartel, aunque con un verso distinto y algunas variantes menores (ms. 4154 BNE, f. 261r y f. 261v-f,. 262v), otra glosa diferente (ms. 3899, f. 65r-f. 66r, dentro de una sección bajo el título común de Versos que se posaran en el Hospital de santa Creu de Bar. ${ }^{\text {na }}$ lo dia dels mors, any 1666), o la simple recuperación del hemistiquio inicial («Yo, ¿para qué nací? / Para alabaros») en unas seguidillas religiosas que no continúan el esquema compositivo del poema original (ms. $3741 \mathrm{BNE}$, p. 46-49). La transmisión impresa de esa octava parece haber sido igualmente fecunda y con similar proyección atemporal. Con escasas variantes, la misma glosa del cartel había venido siendo publicada con otras composiciones desde 1613 hasta 1629 en pliego suelto, arropada en la autoría de Lope de Vega (puede verse, a partir de una de las reediciones, Antonio Sánchez Jiménez (ed.), La Segunda parte del desengaño del hombre (pliego suelto de 1615), de Félix Lope de Vega Carpio, Pamplona, GRISO / Universidad de Navarra, 2004; para la relación y eventual descripción de ediciones, Maria Grazia Profeti, Per una bibliografia di Lope de Vega: opere non drammatiche a stampa, Kassel, Reichenberger, 2002, p. 417-419). Aparte de tales antecedentes, puede tenerse en cuenta, por ejemplo, con significativa contigüidad de los dos poemas del cartel, aunque con algunas variantes, Juan Caramuel Lobkowitz, Primus calamus ob oculos ponens metametricam quae variis currentium, recurrentium, adscendentium, descendentium, nec-non circunvolantium versuum ductibus... multiformes labyrinthos exornat, Roma, Fabio Falconi, 1663, «Apollo centonarius», p. 29-30; o una nueva glosa, con meditación en prosa incluida, 
La otra gran línea de poesía religiosa aglutina distintas manifestaciones del culto a la Virgen, a los santos y, más raramente, a Cristo. La diversidad formal y pragmática es, sin embargo, extraordinaria, y recoge tanto lo atemporal como el particularismo circunstancial. Los carteles a San Juan Evangelista, ligados a la celebración patronal anual, en ocasiones trasladan a los poemas alguna alusión aislada a la fiesta, como, en algunos madrileños, la ponderación del desvelo de sus mayordomos -en general, sin precisar nombres, que a veces sí aparecen en los paratextos-, así como del fervor de los impresores o del convento carmelita que la acogía; sin embargo, no es nota obligada, y en otros análogos ningún verso delata su origen festivo. Los carteles barceloneses dedicados a Santo Tomás de Aquino [no 10 y no 16] también dan la impresión, en una concentración temporal que no obsta para transparentar su parentesco con otros pliegos y carteles de cronología más amplia, de su vinculación con fiestas periódicas, posiblemente en el dominico Colegio de Santa Catalina. De forma más general, aunque algunos de estos textos a Santo Tomás también participen de las características del género, otros carteles recogen la popular y persistente tradición de los «gozos» de tema hagiográfico, con frecuencia acompañados de un breve texto litúrgico conclusivo $\left[n^{\circ} 4, n^{\circ} 17 \text { y no } 33\right]^{67}$. No faltan carteles con poemas destinados al canto, como la "fuga" y el romance narrativo, con rasgos típicos de coplas de ciego, que se dedican a Santo Tomás de Aquino [no 8], o como las quintillas del licenciado Ramos del Castillo a Santa Rosa de Lima, cantadas por la Capilla Real en el Convento de santo Domingo el Real [no 43] ${ }^{68}$. La santa peruana también protagoniza un cartel del mismo autor, posiblemente posterior a las fiestas, con unas quintillas jocosas para un certamen poético

en Gabriel de Artabe y Anguita, Diario espiritual, glossa mýstica de la octava que dice: "Yo para qué nací?» etc. en siete consideraciones, conferidas a las principales virtudes, y prodigios de San Francisco Xavier, [Madrid], Juan de Buitrago, 1732.

67. Sobre la tradición poética y editorial de los gozos pueden citarse, entre otros, los clásicos estudios de Joan Baptista Batlle, Los Goigs a Catalunya, Imprenta Altés, Barcelona, 1924; y Joan Amades y Josep Colomines, Imatgeria popular catalana. Els Goigs, Barcelona, Orbis, [¿1940?]. Amplia y actualizada información crítica sobre recursos electrónicos de interés para el subgénero puede verse en Nora Vela, "Los goigs o gozos a través de recursos electrónicos», BiD: Textos universitaris de biblioteconomia i documentació, 23 (2009) [Revista electrónica: http://www.ub.edu/bid/].

68. El poema fue publicado, con dos estrofas menos y ligeras variantes, en Nicolás Matías del Campo y de la Rinaga, Rasgo breve, disceño [sic] corto del religioso culto que la nobleza peruana consagró en el Real Convento de Santo Domingo de esta Corte a la bienaventurada Rosa de Santa María... en obsequio de su solemne Beatificación, Madrid, Mateo de Espinosa y Arteaga, 1668, cuya noticia debemos a Esther Borrego. Aparece, tras la relación, en una sección sin foliar con villancicos y «letras sueltas», h. 11v-h. 12r. 
en Úbeda por su beatificación [no 44]; y por el mismo motivo, en Granada, otro cartel, ya sí concebido en el marco de las celebraciones, aprovecha la laudatio de la santa dominica para la propaganda de la congregación jesuita encargada de los actos devotos de uno de los días [no 48 ${ }^{69}$. Por su parte, un cartel valenciano anuncia las próximas fiestas por la canonización de San Pedro Pascual, rematando con algunas redondillas los pasajes en prosa sobre los festejos programados y los detalles hagiográficos del homenajeado [ $\left.n^{\circ} 22\right]$, contexto atípico para un contenido poético que se revela secundario, aunque, por ello mismo, resulta elocuente a propósito de la versatilidad situacional y la amplia estima de la versificación.

Frente a esta gama de santos - patronos, mentores, protagonistas de fiestas anuales o extraordinarias»- y a la diversidad poética y pragmática de los carteles a ellos dedicados, la devoción cristocéntrica se reduce en este corpus a unas coplas para la dedicación de la capilla de Jesús Nazareno en un colegio jesuita granadino [ $n^{\circ} 37$ y al citado laberinto en quintillas de tema eucarístico, en el marco de una congregación sacramental madrileña [ $\mathrm{n}^{\circ} 18$ ].

Más fecunda, la piedad mariana muestra en toda su riqueza la diversidad de usos y situaciones en que estos carteles cobraron sentido. En torno a advocaciones de fervor local, conventual o parroquial, hallamos tanto unos genéricos gozos a la Virgen de la Merced, publicados en Barcelona [ $\left.n^{0} 34\right]^{70}$, como un par de impresos madrileños de carácter ocasional. Entre prosa y verso - a diferencia del doble folio valenciano citado, no en ostensible convivencia, sino disimulado el uno en la otra en texto a línea tirada-, uno de ellos vuelve a ser el cartel anunciador de una fiesta, ahora la de una hermandad de labradores, con procesión de la Virgen de la Cabeza y posterior acto de culto $\left[n^{0} 35\right]^{71}$; el otro relata la ya celebrada procesión de la Virgen de

69. El cartel poético carece de pie de imprenta; no obstante, el texto alude a la Congregación del Espíritu Santo y a la Compañía de Jesús, y menciona que la fiesta se celebra en domingo, en octubre. Estas precisiones coinciden con los datos aportados en los dos carteles encuadernados a continuación del ejemplar consultado, con el programa de los actos festivos: Aumentos lustrosos a la celebración de la bienaventurada Rosa de Santa María, de la Tercera Orden de Predicadores, Granada, Imprenta Real de Baltasar de Bolíbar, 1668 (el primero, con erratas corregidas a mano; el segundo, sin tales erratas). Es muy posible, pues, que el poema remita a la celebración en Granada de la beatificación de Santa Rosa de Lima.

70. El poema, con frecuentes variantes y algunas estrofas menos, se halla ya en una hoja suelta tamaño folio, con el título de Rogativa que cantan los Cautivos Christianos todas las noches, a la Virgen Santíssima de la Merced, que tienen en la Mazmorra, pidiéndole su libertad: $Y$ han traido a España a los 236 Cautivos que ha rescatado la Religión de N. S. de la Merced en los Reynos de Tetúan y Fez, este año de 1648, [s. 1., s. i., ¿1648?].

71. La fecha del impreso es incierta. Al final menciona que predicará fray Juan de la Concepción, agustino descalzo, "Prior de la devotíssima casa desta Corte, Consultor de la 
la Almudena con motivo del Jubileo de $1652\left[\mathrm{n}^{\mathrm{o}} 20\right]^{72}$, éste desde intereses más cortesanos en su atención a las personalidades eclesiásticas y de la familia real implicadas en el acto. Un tercer impreso madrileño sorprende por su combinación, en este formato de cartel, de contenido poético y documento privado [ $\left.\mathrm{n}^{\circ} 19\right]$ : en realidad, el conjunto queda dominado por un grabado y varios poemas (unos sonetos laudatorios, dedicados a la imagen titular y a la hermandad de Nuestra Señora de Gracia y Socorro; unas décimas, aunque con referencias a la imagen, más atentas a los ideales y beneficios de la congregación); el componente documental, la cédula que debía completarse a mano con los nombres del nuevo hermano y de su esposa, se relega a la parte inferior, donde también constan las obligaciones de estos y sus derechos en caso de enfermedad o muerte. En cierto modo, si no puede dejar de hablarse aquí de "poesía circunstancial», debe reconocerse en ella el matiz atemporal que le presta, de un modo, el documento, y de otro bien distinto, la esperable continuidad del hermano/poseedor del cartel en los valores devotos que expresan los poemas y en la delectación en su lectura.

En todo caso, donde mejor se aprecia la variedad dentro de un mismo tema en circunstancias similares es en los carteles dedicados a la Inmaculada Concepción. Su concentración temporal (casi todos entre 1650-1653 y en 1662) transita varios de los rebrotes locales y nacionales de la polémica concepcionista: en 1650 en Granada, al parecer por el sermón de un dominico contrario a la pía opinión [ $\left.\mathrm{n}^{\circ} 27\right]^{73}$; en 1652 en Madrid, por el incendio de la iglesia del también dominico Colegio de Santo Tomás, que la piedad popular atribuyó a castigo divino por la resistencia de la orden a la doctrina inmaculista $\left[n^{\circ} 50\right]^{74}$; en 1653 , por la adhesión de los centros jesuitas sevi-

Suprema y General y Inquisición [sic]». Hay un fray Juan de la Concepción, agustino recoleto, nombrado Procurador General de Madrid en el décimo Capítulo intermedio General (24 de mayo de 1681); asiste como tal al decimotercero Capítulo General (17 de mayo de 1684), donde le releva en el cargo Mateo de la Encarnación (Fr. Pedro de San Francisco de Asís, Historia general de los religiosos descalzos del Orden de los Ermitaños del gran Padre y Doctor de la Iglesia San Agustín de la Congregación de España y de las Indias. Tomo Cuarto, Zaragoza, Francisco Moreno, 1756, p. 425 y p. 457-458); no se han podido recabar datos posteriores.

72. Da noticia del jubileo y de la procesión Juan de Vera Tassis y Villarroel, Historia del origen, invención y milagros de la sagrada imagen de Nuestra Señora de la Almudena, antigüedades y excelencias de Madrid, Madrid, Francisco Sanz, 1692, p. 475. Junto al cartel poético se conserva un ejemplar del que anunciaba el jubileo, publicado en Madrid por Pablo de Val, 1652 (RAH 9/3746(96)).

73. El suceso dio pie a sonadas celebraciones de desagravio, con representaciones de autos y certamen poético incluidos, que quedaron reflejadas en Luis de Paracuellos Cabeza de Vaca, Elogios a María Santíssima. Consagrólos en suntuosas celebridades devotamente Granada a la limpieça pura de su conçepción, Granada, Francisco Sánchez y Baltasar de Bolíbar, 1651.

74. Da cuenta del suceso Antonio de León Pinelo, quien comenta: «Y siendo esta desgracia 
llanos al reguero de votos concepcionistas adoptados como reglamentarios en numerosas instituciones de varias ciudades $\left[n^{\circ} 42\right]^{75}$; y en 1662 , por la ya citada bula de Alejandro VII, de resonancia festiva nacional [ $\mathrm{n}^{\circ} 32, \mathrm{n}^{\circ} 38$ $\left.\mathrm{y} \mathrm{n}^{\circ} 39\right]$.

Sin embargo, ni todos los poemas desvelan sus circunstancias ni su función u origen son idénticos. Entre ellos, tienen cabida, de nuevo, los textos cantados, unos en las fiestas jesuitas de Granada [no 38 y no 39], otro en el sin duda más selectivo espacio de la Capilla Real madrileña [ $\left.{ }^{\circ} 45\right]$; también productos como los romances mudos, destinados a una lúdica y pública admiración en el marco de fiestas o justas [no 32 (véase además nota 55)]; asimismo, un atípico cartel donde, sin declaración del motivo aglutinante, cinco autores del entorno granadino coinciden en componer y publicar unas décimas sin más alusión a los hechos que alguna velada indicación, imperceptible para quienes no los conocieran $\left[\mathrm{n}^{\circ} 27\right]^{76}$; y en Sevilla, composiciones de tres autores con precisas referencias al contexto festivo del voto concepcionista de las escuelas [ $\left.\mathrm{n}^{\circ} 42\right]$. Ni siquiera falta la soterrada controversia: un poema de desarrollo argumentativo, frecuente en el tema, en sus últimas estrofas alude sin ánimo polémico a las discrepancias de los dominicos, precisamente para presentarlas como ya superadas o superables, al tiempo que niega el designio divino en el incendio de su iglesia madrileña [no 50]. El

tan casual i lastimosa empeço luego el Pueblo a glosarla aplicandola a la opinion de la Concepcion por ser la iglesia de la Virgen Santisima cuyas imagenes se salvaron i de S. Tomas, cuya imagen no aparecio, i añadir circunstancia el dia [14 de agosto, víspera de la Asunción] i la prisa del incendio pues luego se reconocio que era sin remedio. De que resulto (entre la gente vulgar) notable atrevimiento para con los Religiosos Dominicos diciendoles no pocos pesares. [...] Aun en esta estrechura i con solo quatro Religiosos, que no residian mas, los apretava mas el Pueblo amaneciendo a las puertas versos, coplas y retulos de la Concepcion» (Anales de Madrid, ed. de Pedro Fernández Martín, Madrid, CSIC, 1971, p. 349).

75. Se conserva cartel anunciador de los actos sevillanos: Pública celebridad al religioso acto, al solemne juramento, que hazen los estudios de esta ciudad de Sevilla, la Congregación de Nuestra Señora de La Anunciata, los Colegios, y Seminarios de la Compañia de Jesús, en el Colegio de S. Hermenegildo de la misma Compañia, de creer, afirmar, y defender el Mysterio de la Concepción Immaculada de la Virgen Maria Señora Nuestra, en 1 de junio de 1653, [s. 1., s. i., s. a.]. Véase también Manuel Serrano y Ortega, Glorias sevillanas. Noticia histórica de la devoción y culto que la muy noble y muy leal ciudad de Sevilla ha profesado a la Inmaculada Concepción de la Virgen Maria desde los tiempos de la Antigüedad hasta la presente época, Sevilla, Imprenta E. Rasco, 1893 , p. 529-531 y p. 814-815.

76. El primer poema, de Juan de Trillo y Figueroa comienza: «Voz impura, ¿el arrebol / intentas turbar de aquella / clara Matutina Estrella / luziente Madre del Sol?»; y más adelante: «de que fue la Celestial / Reyna que aclamar no quieres, / Bendita entre las mugeres / sin pecado original». Aunque podría entenderse como censura general de cualquier contradictor de la doctrina inmaculista, cobra su preciso sentido en la polémica suscitada por el sermón del dominico Padre Arratia (véase nota 73). 
ejemplar utilizado conserva una censura manuscrita con la autorización condicionada a la supresión de los pasajes tachados, expurgo que se ratifica para la reedición del poema en $1662^{77}$. El dictamen muestra cómo aun la alusión favorable a la conciliación levantaba suficientes suspicacias como para obligar a su supresión; con ello, de paso, el censor mostró la facilidad con que un texto de claras marcas circunstanciales -si es que estas, a su vez, no habían sido interpolaciones «actualizadoras» de un texto anterior- podía convertirse en un atemporal poema devoto apto su publicación diez años después.

Como se ha ido viendo, pues, profanos o religiosos, efímeros o con secretas aspiraciones a ser conservados con esmero, de acendrado virtuosismo editorial o compositivo o bien primariamente utilitarios, este medio centenar largo de carteles poéticos -como posiblemente otros muchos desconocidosrenunciaron a amplias zonas del mundo poético del momento, a muchos de sus temas y a buena parte de la riqueza métrica que se extendía más allá de la gama octosilábica y del soneto. A cambio, con sus galas artificiosas y tipográficas, cuando no con su mera corporeidad exhibida, atrajeron miradas y lecturas, incluso las de quienes apenas habrían pasado las hojas de un pliego en cuarto. Con ello, espacios nada desdeńables de la vida pública y la devoción particular acabaron rindiéndose a su no ser libro de poesía.

77. El ejemplar presenta varias coplas tachadas; abajo, la censura, parcialmente ilegible, reza: «Ynprímase con que no sean las siete últimas coplas y con que se traiga la copia para ver si coresponde $[s i c]$ con su original [¿ंDon Ro ar---de--?].» Más abajo, de otra letra, con el inicio de cada línea cortado: «[----]primirse sin las siete coplas. Madrid y [----] de 1662.» 
BULLETIN HISPANIQUE

\section{INVENTARIO DE TESTIMONIOS ${ }^{78}$}

1) A las reales sumptuosas, y funestas honras, que se celebraron en el Real Convento de Nuestra Señora de la Encarnación, por la serenissima señora doña María Luisa de Borbón, augusta Reyna de España, assistiendo en ellas el Rey nuestro Señor

- LABERINTO. [Redondilla] Con la A roxa que empieces, / Por recinto, centro y lado.

- RETRÓGRADO. [Laberinto] A NO ROCIAR AROMAS, ES AMOR ARA, Y CORONA.

- GLOSSA. [Quintillas] Los Elegantes idiomas / Bien te aclaman, LISI, sabia.

S. 1., pero ¿Madrid?; s. i.; s. a., pero ¿1689?

1 h., doble fol. $(285 \times 420 \mathrm{~mm})$

Madrid, Biblioteca Nacional de España, VE/24-61

Simón Díaz, 1950, V, no 1.308; Simón Díaz, 1977, lám. no [4], reducida; Verso e imagen, p. 105, reducida; Catálogo, no 22, reducida; Díez Borque, 1992, p. 25; Díez Borque, 1999, [lám.] no 12, p. 426; Imagen, [lám.] no 10, p. 79, reducida; Muriel, reproducción.

[Nota. Dos tintas, orla doble completa de adornos, una de ellas enmarcada por filetes, cortada por escudo de Espańa frontal dividiendo la titulación, composición cuadrada tipográfica central enmarcada por filete fino sin rematar por arriba, haciendo caja con el texto y con cruces en las esquinas, inclusión superior e inferior de estrellas, texto superior a una col. e inferior a dos columnas, dividido con columna central de orla partida con adorno.]

2) A San Juan Evangelista, Patrón, y Abogado de los Impressores desta Corte - ROMANCE. DE IUAN la sacra memoria / Recapacitar deseo.

78. En este "Inventario» se recogen todos los carteles que hemos logrado localizar con un ejemplar en la mano; se ofrece una descripción de los mismos: colación, medidas, contenido poético, localización, bibliografía específica, reproducciones (si es que existen) y una breve noticia de su contenido gráfico, sin pretender en ningún caso que sea exhaustiva. Algunas fechaciones son, evidentemente, provisionales y en algún otro testimonio de difícil datación hemos preferido, bien indicarlo, bien eliminarlo. 
S. l. (¿Madrid?); s. i., pero F[ernández]. B[uendía]. y I[ulián de]. P[aredes].; 1683

1 h., doble fol. (300x400 mm).

Madrid, Real Academia de la Historia, AHJ, 9/3656(10) [CCPB000424058-8]

Agulló y Cobo, 1968, pp. 114-115, ed. y lám. no 3, reducida; Simón Díaz, 1977, lám. no [8], reducida; Infantes, 2005, il. no 31, reducida.

[Nota. Triple orla completa de corazones dividida por filetes, grabado del santo con la copa con la serpiente en la mano que corta la orla superior, flanqueado por adornos florales, texto a dos columnas, divididas por columna central de adornos.]

3) A San Juan Evangelista, probando que le tocan tres ábitos, el de Christo, el de Sancti Espiritus, y el de San Juan, y no el de Santiago

- DÉZIMAS. POdemos decir de Dios, / Que quiso en la Cena Real.

S. 1. (¿Madrid?); s. i.; s. a., pero: ¿1683?

1 h., doble fol. (290x404 mm).

Madrid, Real Academia de la Historia, AHJ, 9/3656(11)

[CCPB000424059-6]

Agulló y Cobo, 1968, pp. 115-116, ed. y lám. no 4, reducida; Simón Díaz, 1977, lám. no 9, reducida; Infantes, 2005, il. no 32, reducida.

[Nota. Triple orla completa de adornos, estampeta del santo escribiendo sobre paisaje que corta la orla superior, texto a dos columnas, divididas por columna central de adornos y remate de la última estrofa a una col., flanqueada por dos adornos florales.]

4) Admirable vida de Santa Rita de Cassia, de la Orden de San Agustín Abogada de las viruelas escrita Por vn Devoto suyo

- [Tiranas] Contar quiero las virtudes, / de vna Santa solo en cifra.

Barcelona, Josep Moyá Libreros, s. a., pero: ¿1685?

1 h., doble fol. $(293 \times 415 \mathrm{~mm})$ 
BULLETIN HISPANIQUE

Barcelona, Biblioteca de Cataluña [No Registro: 9962].

[Nota. Composición a cuatro columnas, divididas por piezas de adorno; en el encabezamiento grabado de la Santa y al pie: «SANTA RITA DE CASSIA», partiendo la titulación.]

5) Al Águila Misteriosa San Juan Apóstol y Evangelista, en el Martyrio de la Tina

- ROMANCE. CÁndida brillante ROSA, / En cuya pompa se advierte.

Madrid; Imprenta de Villa-Diego; 1683

1 h., doble fol. (310x440 mm).

Madrid, Real Academia de la Historia, AHJ, 9/3656(12)

[CCPB000424079-0]

Agulló y Cobo, 1968, pp. 106-107, ed. y lám. 1, reducida; Simón Díaz, 1977, lám. no [6], reducida; Infantes, 2005, il. n 29, reducida.

[Nota. Dos tintas, composición exenta en forma de retablo, arriba águila exployada con corona que aprieta en las garras una cartela con la leyenda «S. P. Q. P.» en la filacteria que divide el título y debajo grabado exento del santo con la copa con la serpiente en la mano sobre pedestal de adornos, inserta en doble hornacina de adornos, flanqueada en las calles por árboles formados de adornos, el texto a dos columnas, divididas por columna central de adornos, enmarcado en forma geométrica de copa.]

6) Al águila misteriosa San Juan Evangelista

- [Quintillas] Oy mi Talía se inclina / Necia, à vna pretensión vana.

- [Quintillas] Rendidos dos corazones / Imitan nobles afectos.

Madrid; En la Imprenta de Antonio González de Reyes, «Baltasar Gómez fecit»; 1689

1 h., doble fol. (360x465 mm).

Madrid, Biblioteca Nacional de España, VE/25-79 
Catálogo, no 49, reducida; Infantes, 2002; Infantes, 2005, il. no 35, reducida.

[Nota. Composición en forma de retablo dentro de orla completa de adornos, frontal complejo en forma de copa ¿aguilada? construido todo de adornos y calles de composición vertical con nichos de adornos sobre pedestal rematados en cruces que insertan las estrofas.]

7) Al amante más fino, al valido más amado, [San Juan Evangelista]

- [Romance] A La más gloriosa PLVMA, / Al más levantado BVELO.

Madrid; Imprenta Real, por Mateo de Llanos; 1683

1 h., doble fol. $(285 \times 410 \mathrm{~mm})$

Madrid, Real Academia de la Historia, 9/3656(8).

[CCPB000424080-4]

Agulló y Cobo, 1966, p. 193, ed. y lám. no 1, reducida.

[Nota. Dos tintas, dentro de doble orla completa de adornos, composición en forma de custodia de adornos, en la parte superior, de forma central, se inserta circularmente «S. IVAN EVANGELISTA» y «PRINCIPE DEL CIELO, / TORRE DE LA IGLESIA, / CVSTODIA DE MARÍA, / PIELAGO DE VIRTUDES.», flanqueada, superiormente por dos faroles realizados de adornos, en medio dos velas realizadas de adornos y en la parte inferior, dos columnas con el texto delimitado por adornos y cartelas con los datos de imprenta; dos estampetas de castillo y león entre las velas.]

8) Al angélico Doctor de la Iglesia S. Thomás de Aquino. Año 1656

- FVGA. A La Escuela de Aquino muchachos / Que enseña, que escribe, q[ue] no ay más q[ue] ver.

- ROMANCE. SILENCIO, Señores míos, / Mientras siguiendo mis coplas.

S. 1.; s. i.; 1656

1 h., doble fol. (300x435 mm).

Madrid, Biblioteca Nacional de España, VE/205-48

[CCPB000039554-4] 
Catálogo, no 50, reducida.

[Nota. Orla completa de adornos, composición a cuatro columnas, separadas por filetes.]

9) Al benjamin de Christo, al hijo segundo de Maria, S. Juan Evangelista, en el martyrio de la tina. El arte de la imprenta desta Villa de Madrid repite sus cultos

- [Romance] SOBERANO invicto MÁRTYR, / Que con SAGRADA Ossadía.

Madrid; «Mayordomos Juan Infançón, Antonio de Reyes», «Francisco Gómez, fundidor [...] fec[it].»; 1689

1 h., doble fol. $(295 \times 450 \mathrm{~mm})$

Madrid, Biblioteca Nacional de España, VE/25-35

[CCPB000036810-5]

Catálogo, no 52; Infantes, 2005, il. no 39, reducida.

[Nota. Dos tintas, composición exenta en forma de retablo que simula una gran copa, arriba estampeta del santo, escribiendo sobre fondo de paisaje, con orla completa de adornos sobre basamento y remate triangular, inserta en altar lobulado con remate de dos basamentos con velas, flanqueado en las calles por dos custodias circulares de adornos, abajo basamento rectangular de triple fila de adornos que simula una peana, donde se incluye el texto a tres columnas, divididas por columnas centrales de adornos y sobre él dos cartelas de adornos con los datos del taller y la fecha, flanqueadas por dos figuras de árbol compuestas con adornos.]

10) Al capitán de la Fe, e invicto Marte de la Iglesia el Angélico Doctor Santo Thomás de Aquino

- ROMANCE. PLaça, Estrellas del Olimpo; / plaça al Rey de los Planetas.

- AL FENIS MÁS CASTO de la Iglesia Santo Thomás de Aquino. DÉZIMA. DE nuestra Fe en el Iardín, / Entre vulcanes de amor.

- A EL ÁGUILA REMONtada de la Fè Santo Thomás de Aquino. DÉZIMA. NAzes al Nido de Aquino, / Águila de Imperio mayor. 
Barcelona; En casa de Juan Jolís, a los Algodoneros; 1680

1 h., doble fol. $(260 \times 400 \mathrm{~mm})$

Valencia, Biblioteca Universitaria, BH Mss. 821(52)

[CCPB000145124-3]

Gisbert/Ortells, I, no 106.

[Nota. Doble orla completa de adornos, en su interior título y debajo estampeta del Santo con filacteria: «BENE SCRIPSISTI DE ME TOHMA.», flanqueada por dos adornos florales, composición superior a tres columnas, separadas por columnas de adornos; abajo composición a dos columnas, enmarcadas en orlas laterales de adornos y gran orla central con dos piezas. Al fin: «Con licencia».]

11) Al Coronista Sagrado al Fénix de la escritura, al Regalado de Christo San Juan Evangelista

- [Cuartetas] Prodigiosíssimo Enigma, / Ya no te alcança el Ingenio.

- [Romance] CORONADA la BELLEZA / DE JUAN, por acreditada.

Madrid; Imprenta Real, Mateo de Llanos, «Mayordomos Infanzón Reyes»; 1689

1 h., doble fol. $(330 \times 370 \mathrm{~mm})$

Madrid, Biblioteca Nacional de España, VE/23-38

[CCPB000041802-1]

Catálogo, no 55, reducida; Infantes, 2005, il. no 34, reducida.

[Nota. Dos tintas, composición en forma de retablo, la calle central de cinco columnas de adornos donde se inserta una estampeta del santo con el águila al pie sobre paisaje, coronada por remate triangular con cruz latina y las laterales de cinco columnas, coronadas con remate triangular y círculo, basamento de cinco líneas horizontales, la titulación y el enigma en los nichos superiores, enmarcados en cartelas de adornos y el romance en los nichos internos inferiores.] 
12) Al divino Protonotario de la Iglesia, al Sol, y Sal del Evangelio, al Hijo del Trueno, y Rayo de los Hereges, al Tesorero de Dios, al Comendador, y Capellán Mayor de María, a su Adoptivo, Hijo y Hermano de Christo, al Apóstol, al Mártyr, al Doctor, al Virgen, al Confessor, al Profeta, al Evangelista San Juan, y al Amado de Dios, por anthonomasia

- [Romance] ES S. JVAN CÁLIZ que encierra,/ Es Sangre que extravenó.

S. 1., pero: Zaragoza; Por los Herederos de Diego Dormer; 1694

$1 \mathrm{~h}$, doble fol. $(285 \times 380 \mathrm{~mm})$

Huesca, Biblioteca Pública, B-52-8035(65)

[CCPB00730880-9]

[Nota. Dos tintas, orla doble completa, debajo del título estampeta del Santo, flanqueada por dos águilas compuestas con piezas tipográficas, con filacteria en el pico: «S. JUAN.» y «EVANGELISTA.»; el texto a dos columnas divididas en toda su extensión por una gran copa con peana formada de piezas tipográficas, que representan la prolongación de la imagen y de las dos águilas.]

13) Al Extático Virgen, Mártyr Apóstol y Evangelista San Juan, contemplándole en el ardiente fervor de la tina

- ROMANCE. POder eterno, a qué agrado / A qué cumbre, a qué región.

S. 1., pero ¿Madrid?; s. i., pero ¿Fernández Buendía y Julián de Paredes?; 1683

1 h., doble fol. (290x403 mm)

Madrid, Real Academia de la Historia, 9/36356(9)

[CCPB000424083-9]

Agulló y Cobo, 1968, p. 114, ed. y lám. 2, reducida; Simón Díaz, 1977, lám. no [7]; Infantes, 2005, il. no 30, reducida.

[Nota. Orla completa de tres filas de adornos, cortada en la parte superior por un grabado del santo con la copa con la serpiente en la mano, firmado «DC. Sc.», flanqueada por dos cestas florales, texto a dos columnas, dividido por columna central de adornos, sobre esta columna, arriba la estrofa enmarcada por orla de adornos, flanqueada por dos composiciones ovaladas de adornos 
con las leyendas «D. D. I.» y «D. V.», bajo ella una composición especular, en el centro «I. D. P. H. M.», flanqueada por la palabra «Año» y «683.».]

14) Al glorioso Apóstol, Virgen y Mártir San Juan Evangelista, careándolo con Dios, por sus heroycas virtudes

- ROMANCE. A Mi discurso la Fè, / Cautive, porque si no.

S. 1., pero ¿Madrid?; s. i., pero ¿Fernández Buendía y Julián de Paredes?; s. a., pero ¿1683?

1 h., doble fol. $(295 \times 430 \mathrm{~mm})$

Madrid, Biblioteca Nacional de España, VE/23-45

[CCPB00026519-2]

Catálogo, no 62, reducida; Infantes, 2005, il. no 37, reducida.

[Nota. Dos tintas, orla completa de triple fila de adornos, la central entre filetes, cortada en la parte superior por grabado del santo con la serpiente en la mano, firmado "DC. Sc», texto a dos cols., dividido por columna central de adornos, sobre ella la estrofa enmarcada por orla de adornos y bajo ella remate de texto, flanqueado por rombo de adornos.]

15) Al insigne Mártyr, al glorioso Apóstol, al soberano Evangelista, San Juan, en el riguroso martyrio de la tina

- ROMANCE. ÁGUILA Excelsa, y Divina, / Cuya vista sabia, y fiel.

Madrid; Juan Infanzón y Antonio de Reyes; 1689

1 h., doble fol. (292x445 mm), recortado en el margen izquierdo

Madrid, Biblioteca Nacional de España, VE/23-39

Catálogo, no 66, reducida; Infantes, 2005, il. no 36, reducida.

[Nota. Orla triple completa de adornos, cortada en la parte superior por una composición que incluye una estampeta, inserta en una hornacina de adornos y flanqueada por dos piezas florales, texto a dos columnas, separadas por columna central de orla que enmarca una pieza y las estrofas divididas por adornos.] 
16) Al invicto baluarte de la Fe, al angélico, y quinto doctor de la Iglesia Santo Thomás de Aquino

- REDONDILLAS. THomás, Fuente de la Fè, / que en cristales se desata.

- Al más reluciente Escrivano, aprovado por Christo, el Angélico Doctor. DÉZIMA. LUZ del Orbe reluciente, / Luz del mundo superior.

- Al Illustre Pendón, y insigne Vandera de la Fè, el Quinto Doctor. DÉZIMA. ESTE estruendo militar, / Este Pendón, y Vandera.

Barcelona; En casa de Juan Solís, a la Calle de los Algodoneros; 1680 1 h., doble fol. $(270 \times 380 \mathrm{~mm})$

Valencia, Biblioteca Universitaria, BH Mss. 821(51) [CCPB000145126-X]

Gisbert/Ortells, I, no 109.

[Nota. Doble orla completa de adornos, en su interior título y debajo el texto a dos columnas, cuyas iniciales forman un acróstico con las mayúsculas invertidas: «THOMAS DE AQUINO», en el centro gran grabado del Santo, rematado con adornos enmarcados que ocupan toda la base de la ilustración; debajo composición a dos columnas, encuadrada con orlas horizontales de adornos, orlas laterales de adornos y gran orla central con dos piezas.]

17) Al portento de virtudes, assombro de los siglos, maravilla de las altezas de Dios, El grande San Nicolás de Bari, arzobispo de Mira, prohijado de España

- GOZOS. [Redondilla] PVesto que entre los mayores / Os aplauden peregrino.

- [Copla castellana] PAtàra dicha ha logrado / En tan grande nacimiento.

S. l.; s. i.; s. a., pero: ¿1684?

1 h., doble fol. $(305 \times 430 \mathrm{~mm})$

Madrid, Real Academia de la Historia, 9/3576(77).

[CCPB000416774-0]

[Nota. Doble orla completa de adornos y filete, cortada en la parte superior, con inserción de grabado del santo, con pie: "RETRATO DE SAN NICOLAS DE BARI»; texto a tres columnas, divididas por una columna de adornos. Al pie «ANTIPHONA» $\mathrm{y}$ «OREMVS».] 
18) Alabado sea el santíssimo Sacramento, y la puríssima Concepción de la Virgen María Señora nuestra, concebida sin mancha de pecado original en el primer instante de su ser natural. Amén

- [Octava] EN aqueste ingenioso Laberinto, / sin faltar al sentido, y consonancia.

- [Laberinto] [Quintillas] Aquel Soberano Autor, / Aquel increado Oriente.

S. 1., pero ¿Madrid?; s. i.; s. a., pero ¿1654-1658?

1 h., doble fol. $(295 \times 435 \mathrm{~mm})$

Madrid, Biblioteca Nacional de España, VE/180-1

Simón Díaz, 1982, no 10; Catálogo, no 79, reducida.

[Nota. Orla completa, título cortado en el centro por un cáliz y la octava enmarcada en orla de adornos y flanqueada por cruces griegas de adornos, el laberinto en cartelas delimitadas por filete. Al pie: normas para desarrollar el Laberinto y, a continuación, «Todo a mayor gloria del altíssimo Sacramento, y sujeto a la corrección de la Santa Cathólica Romana Iglesia. Lo dedica un indigno Esclavo del Santíssimo, en su Congregación del Cavallero de Gracia».]

19) Alabado sea el Santissimo Sacramento del altar, y la Virgen Santissima concebida sin pecado original. Sonetos, y dézimas a la Virgen Santissima de Gracia, y Socorro

- [Soneto] Esta sagrada Imagen de María, / Tiene de antigüedad más de mil años.

- [Soneto] O dichosa Hermandad! Apostolado! / De doze deuotísimos varones.

- Carta de la Hermandad de Nuestra Señora de Gracia, y Socorro, sita en la Parroquial del Señor San Juan desta Villa de Madrid. DÉZIMAS. DE GRACIA, y Socorro son / los nombres desta Señora.

S. 1., pero ¿Madrid?; s. i.; s. a., pero ¿1653?

1 h., doble fol. $(270 \times 390 \mathrm{~mm})$

Madrid, Real Academia de la Historia, 9/3576(78).

[CCPB000416776-7] 
[Nota. Orla simple completa de adornos, en interior, arriba grabado central con la imagen de la Virgen: "NVESTRA SEÑORA / ES GRACIA / Y SOCORO [sic] 1653", flanqueado por los dos sonetos, en la parte inferior el texto a cuatro columnas, divididas por columnas de adornos. Al pie: «Sentóse por Hermano [hueco para rellenar el nombre] y su mujer [hueco para rellenar el nombre]» $y$, a continuación, texto en prosa sobre las obligaciones de los miembros de la Hermandad, con anotación manuscrita.]

20) Francisco de Alfantega y Cortés, Fervorosas alabanzas, y elogios a este Santissimo Iubileo, del qual no ha auido otro exemplar en España, en que se da noticia, de como la deuota, y nouilissima Congregacion de la Virgen Santissima de la Almudena sacó en Processión su antigua, y Sacra Imagen; Aqui se declara en la forma, y con la grandeza, Real aparato, y pompa con que saliò. Por Francisco de Alfantega, $y$ Cortès

- [Romance] AL Sagrado Jubileo / En quien se repiten todas.

Madrid; Con Licencia, por Pablo de Val; 1652

1 h., doble fol. $(295 \times 405 \mathrm{~mm})$

Madrid, Real Academia de la Historia, 9/3746(95)

[CCPB000471728-7]

Agulló y Cobo, 1969, ed., pp. 469-474; Simón Díaz, 1986, no 1.

[Nota. Orla completa de adornos y filete, cortada arriba por la inserción de un escudo eclesiástico.]

21) Gerónimo Ares de Vaamonde, [...] Vivió el Rey N. S. treinta y nueve años menos quatro días: el año tiene 365. días: los treinta y nueve años menos quatro dias con seis Visiestos, que corrieron en los treinta y nueve años, hazen 14237. dias

- [Cuarteta] TÉrminos tienen los días / Del Rey, como de Pleveyo.

S. 1., pero Madrid; s. i., pero: Hallaráse en la Imprenta [Real], enfrente del Correo de Italia; s. a., pero ¿1700?

1 h., doble fol. $(296 \times 417 \mathrm{~mm})$

Madrid, Biblioteca Nacional de Espańa, VE/501-64.

Aguilar Piñal, I, no 2.362; Catálogo, no 128, reducida; Infantes, 1996, ed. 
[Nota. Todo el cartel tiene exclusivamente una composición tipográfica de distintos cuerpos, presentada en tres columnas, dos con mayúsculas y sus valoraciones numéricas para desarrollar las correspondencias numerales y una tercera con la cuarteta, la solución y cuatro citas latinas.]

22) Ayroso siempre en desempeños se a realçado el sagrado, Real, y Militar Orden de nuestra señora de la Merced Religión de Cautivos [...]

- [Cuartetas] El nombre de Santo quadre / à Pedro en blasón felice.

Valencia: Gerónimo Vilagrasa, «Impressor de la Ciudad, y de la Inquisición»; 1674

1 h. doble fol $(295 \times 440 \mathrm{~mm})$

Valencia, Biblioteca Universitaria, BH Var. 295(08)

[CСРВ0001301670-7]

Gisbert/Ortells, II, no 4510.

[Nota. Orla completa de adornos con el texto a línea tirada, partido en dos divisiones por doble orla central de adornos, con los poemas insertos dentro de la redacción. Al fin: «CON LICENCIA».]

23) Fernando de Bustamante Bustillo, Epilogando a la rápida estación del sol el presuroso tránsito lamentable de la católica Reyna N. S. Doña María Luisa de Borbón, sol que cielos goze. Dedicado al Señor D. Manuel García de Bustamante, Cavallero del Orden de Santiago, y del Consejo de Hazienda de S. M. etc. Del militar don Fernando de Bustamante Bustillo. Epigramma acróstico, alegórico al Sol, finalizado en $O$

- [Soneto] De el Monarca de Luz, Rapto PortentO / Oy es la Reyna, en Solio IluminadO.

- Soneto. O Reyna Obscurecida, [...] enso Velo! / En qué Lúgubre Pluma ya oy se encierra.

S. l., pero ¿Madrid?; s. i.; s. a., pero ¿1689?

1 h., doble fol. $(295 \times 440 \mathrm{~mm})$

Madrid, Biblioteca Nacional de España, R/2634, tras fol. 98 
Simón Díaz, 1950, VI, no 5.755; Cózar, p. 524, fig. 150, reducida.

[Nota. Orla completa de adornos que enmarca la composición, debajo del título, con orla completa de adornos la disposición de los versos como rayos solares partiendo de un grabado central del Sol; debajo a una columna el texto, flanqueado por dos florones.]

24) Ignacio de Camargo, Batallón de las mayores excelencias, y prerogativas, del glorioso Apóstol San Juan Evangelista, en metáfora de una escala mysteriosa por donde va subiendo en cuerpo y alma al cielo. Discántala por su devoción el Padre Camargo, en gracia de los impressores en su fiesta de Porta Latina

- [Romance] DE Títulos, y grandezas / Os hizo el cielo vna escala.

S. 1., pero ¿Madrid?; s. i.; s. a., pero ¿1689?

1 h., doble fol. $(300 \times 420 \mathrm{~mm})$

Madrid, Biblioteca Nacional de España, VE/206-87

[CCPB000038204-3]

Simón Díaz, 1950, VII, no 3.615; Simón Díaz, 1983, p. 75; Catálogo, no 222, reducida; Infantes, 2005, il. no 38 , reducida.

[Nota. Orla completa cortada en la parte superior por grabado del santo con la copa con la serpiente en la mano, texto a tres columnas, enmarcado y divididas por filete doble.]

25) Alonso Cidiel y Torres, Romance acróstico endecasýlabo, a la muerte de la Reyna nuestra señora doña María Luisa de Borbón, Reyna de España, que goza de Dios. Ofrécele rendido un noble sentimiento, a la lealtad más fervorosa, sin que lo decoroso estrañe lo no advertido de su inculto estilo, pues lo obsequioso espera le logre lo bien visto. Don Alonso Cidiel y Torres

- [Romance endecasilábico] El duro yugo, del rigor violento, / Postrada la atención, o más confusa.

S. 1.; s. i.; s. a., pero ¿1689?

1 h., doble fol. $(290 \times 420 \mathrm{~mm})$

Madrid, Biblioteca Nacional de España, VE/24-21 
[CCPB000039659-1]

Simón Díaz, 1950, VIII, no 4.201; Catálogo, nº 269, reducida.

[Nota. Orla completa de adornos, texto a tres columnas, dividido por filetes centrales que incluyen un acróstico inicial cada cuatro versos con las mayúsculas invertidas: "DONA MARIA LVYSA DE BORBON REYNA DE ESPANA.».]

26) Devociones, que encargaron en Madrid, Granada, Sevilla, Málaga, y en Alcalá de Enares, los Padres Missioneros de la Compañia de Jesús, y son muy importantes para conservar la Gracia de Dios

- [Tercerillas] SI CON LOS FIELES DIFUVNTOS / TVVIERES MISERICORDIA.

- [Pareados] EN LA CASA DEL QUE IVRA, / NO FALTARÁ DESVENTVRA.

- MIRA QVE TE MIRA DIOS.

- [Quintilla] NVMERO DETERMINADO / TIENE EL PECAR, Y LO SABES.

- [Pareado] CONFIESSA ESSE PECADO, / NO SEA QVE AMANEZCAS CONDENADO.

S. 1.; s. i.; s. a., pero después de 1672

1 h., doble fol. $(290 \times 390 \mathrm{~mm})$

Madrid, Biblioteca Nacional de España, Ms/18433, fol. 119

Catálogo, no 367, reducida.

[Nota. Orla doble completa de adornos, texto en prosa a línea tirada y dividido en cuatro columnas, en la última, con mayúsculas y en composición en obelisco, intercalados los poemas.]

27) Dézimas a la Inmaculada Concepción de Nuestra Señora, de diferentes Autores

- [Décimas] De D. Iuan de Trillo. VOZ impura, el arrebol / intentas turbar de aquellas.

- [Décimas] Del L[icenciado]. Iuan de la Vella. Del sacro honor de 
MARÍA, / que del mismo Dios fue honor.

- [Décimas] De Diego Ferná[n]dez Solana. Libre fue vuestra hermosura / cuando al concebir se fragua.

- [Décimas] De Gabriel Martínez. Al infundiros el Alma / tanto la gracia corrió.

- [Décimas] De D. Pedro de la Cueva. De gracia en vuestra pureza / por gracia, o Virgen se vè.

Granada; Francisco Sánchez y Baltasar de Bolívar; 1650

1 h., doble fol. $(275 \times 380 \mathrm{~mm})$

Palma de Mallorca, Biblioteca de la Fundación Bartolomé March, Ms. 104V2-25 (olim: Ms. 23-3-10), encuadernado entre los folios 90 y 91.

Simón Díaz, 1950, IX, no 2.387; Jerez de los Caballeros, ed.

[Nota. Impresas por una sola cara, a seis columnas. Al fin: «CON LICENCIA».]

28) Dézimas al desengaño de la vida, y prevención para la muerte

- [Décimas] QVANDO Tu curiosidad / Te ha de obligar a leer.

S. 1.; s. i.; s. a., pero ¿1670-1675?

1 h., doble fol. $(315 \times 440 \mathrm{~mm})$

Madrid, Biblioteca Nacional de Espańa, VE/501-59

Catálogo, no 349, reducida.

[Nota. Orla completa de adornos, el texto a cinco columnas, dividido por columnas de adornos.]

29) Dézimas, en donde resumidos están los sermones, que predica[n] en sus Missiones por toda España, con orden de su Santidad, los Padres Predicadores Apostólicos, de la Orden Seráfica de N. P. S. Francisco; y también las Saetas Espirituales, que van cantando por las calles en las Processiones que hazen en sus Missiones

- [Tercerillas y pareados] COnfiéssate pecador, / que quando más descuydado. 
- [Décimas] Plensa que te has de morir, / Piensa q[ue] ay Gloria, e Infierno.

S. 1.; s. i.; s. a., pero ¿1670-1680?

1 h., doble fol. $(220 \times 310 \mathrm{~mm})$

Granada, Biblioteca Universitaria, BHR/A-031-126(39-5) y (42-6)

[Nota. Orla completa de adornos, a tres columnas, divididas por columna de adornos. Al fin de cada plana se encuentran dos textos en prosa, el primero con la mención de entregarse como «limosna» y el segundo una larga amonestación sobre la confesión de los pecados.]

30) Fray Diego García, [Romance mudo geroglífico literal] [...] Universidad de Alcalá de H[enares ...] Príncipe N. S. Philippo Próspero el Desseado, \& cc. En 6. de Febrero de 1658

- [Romance] El Autor deste Romance, / Co[n] ser hombre de más letras.

S. 1., pero Alcalá de Henares; s. i., pero Colegio de Santo Tomás; s. a., pero 1658

1 h., doble fol. (¿?)

Biblioteca privada, Variarum 31, doc. 31

Gonzalo García, pp. 137-142 y lám. 2, p. 149, reducida.

[Fray Diego García, Llave con que se abre, y entiende el Romance mudo geroglifico literal, al nacimiento del Principe, s. l., pero Alcalá de Henares; s. i.; s. a, pero ¿1658?, 1 h., fol.; [Quintilla] Por sacarte de cuydado, / La Llave te doy, Lector, [Romance] PINTADO. Vade. Víctor. Estudiantes. / Capillas. Bonetes. Vecas [y] LEYDO. Va de. V.íctor. Estudiantes. / Capillas. Bonetes. Vecas. Biblioteca privada, Variarum 31, doc. 32; Gonzalo García, pp. 137142 y lám. 3, p. 150, reducida.]

[Nota. Conjunto de 40 cartelas en forma de estauroteca con grabados exentos, flanqueado a la derecha por el texto a dos columnas.]

31) [Glosas de "¿Yo para qué nací? Para saluarme» y de «Oí, palpé, gusté, vi, y tuue olfato"].

- [Octava] YO para qué nací? Para saluarme / Que tengo de morir? 
Es infalible. Glossa. YO cómo vine al mundo? Condenado, / Dios cómo me libró? Dando su vida.

- [Octava] OÍ, palpé, gusté, vi, y tuue olfato, / Viuí con carne, sangre y sentimiento. Parte I. Glossa. SI quieres ver el fin triste que espera / A todas nuestras vanas fantasías.

Madrid; Imprenta Real, Véndese en casa de Juan de Valdés, enfrente del Colegio de Atocha; 1652

1 h., doble fol. $(295 \times 400 \mathrm{~mm})$

Madrid, Real Academia de la Historia, 9/3746(87 y 88)

[CCРB000477302-0 y ССРB000466948-7]

[Nota. En principio, cada hoja está orlada, con una fila de adornos simples, de manera independiente, con pie de imprenta solo en una de ellas, la segunda con grabado de esqueleto exento; encuadernado como si fuera cartel y pone «PARTE I.» Parece una primera hoja, tal vez ¿fol.?, a la que luego se le han añadido otras "partes». No está totalmente clara su condición editorial de cartel en doble folio, no obstante, preferimos incluirlo.]

32) Gerónimo González Velázquez, Retórico (aunque mudo romance) a la Inmaculada Concepción de N. Señora la Virgen María madre de Dios. Dedicado a la Excelsa, Sacra, y Real Magestad Cesárea de Don Felipe IV, el Grande, Rey de las Españas. Compuesto por Gerónimo González Velázquez

- Romance. COrazones, Almas Fieles, / Festeja la Gloria Grande.

- Notas a este retórico romance mudo. Vn Pintor en esta Corte, / procurando aventajarse.

Madrid; María de Quiñones, «Dibuxada, y abierta la estampa por el mismo autor»; 1662

1 h., doble fol. (390x725 mm)

Madrid, Biblioteca Nacional de España, VE/181-32

[CCPB000120488-2]

García de Enterría, reducida; Díez Borque, 1992, p. 32, reducida; Verso e imagen, pp. 124-125, reducida; Catálogo, no 463, reducida; Díez Borque, 1999, [lám.] no 17, p. 430, reducida; Gonzalo García, lám. 5, p. 153, reducida; Imagen, [lám.] 13, pp. 82-83, reducida. 
[Nota. Conjunto de 40 cartelas en forma de estauroteca con grabados exentos, flanqueado por los textos, a la izquierda a dos columnas, divididas por columna central de adornos y a la derecha a una columna. Al fin: «CON LICENCIA».]

33) Gozos de la Virgen Santa Gertrudis por un devoto esclavo suyo

- [Cuarteta] CErtrudis [sic] Virgen gloriosa, / y Esposa del sumo Dios.

Barcelona; Gabriel Bro; 1699

1 h., doble fol $(310 \times 425 \mathrm{~mm})$

Barcelona, Biblioteca de Cataluña [No Registro: 9953, XLIIV]

Batlle, p. 112, con reproducción reducida, en nota, p. 126, aclara: «Aquests goigs son de doble mida que'ls altres».

[Nota. Orla completa, debajo del título, estampeta de la Santa, flanqueada por dos ilustraciones especulares compuestas de adornos; texto a tres columnas, con divisiones centrales de columna de adornos. Al fin: dos alocuciones latinas, más un «OREMUS» y «CON LICENCIA».]

34) Gosos [sic] de Nuestra Señora de la Merced redención de cautivos christianos

- [Cuarteta] O Diuina Emperadora / más que rosa en hermosura!

Barcelona; en casa de Matheuat, delante de la Rectoría de Nuestra Señora del Pino; 1667

1 h., doble fol. $(320 \times 430 \mathrm{~mm})$

Madrid, Biblioteca Nacional de España, VE/142-71

[CCРB000120494-7]

Catálogo, no 468, reducida.

[Nota. Orla completa de adornos, en el interior gran grabado de la Virgen de la Merced, flanqueado por ochos piezas florales, texto a tres columnas, divididas por columnas dobles de adornos. Al fin: Vila Vic[¿ario?]. Gen[¿enral?].\& Offic[;io?]] 
35) Los claveles y rosas, lirios, y palmas [...]

- [Seguidillas] Los claveles y rosas, / lirios, y palmas.

- [Endecasílabos] Al florido Mayo los labradores, / Señora, oy os assisten festivos.

- [Romance irregular] En presençia de la cabeça, / la mayor joya, y presea.

- [Romance irregular] O dichosos sagitarios! / paz, y cabeça son valientes.

S. 1., pero ¿̇Madrid?; s. i.; s. a., pero ¿1659-1668?

1 h., doble fol. $(295 \times 430 \mathrm{~mm})$

Madrid, Biblioteca Nacional de España, VE/65-11

Catálogo, no 274., reducida.

[Nota. Texto en prosa exento a línea tirada, los poemas se deducen de la lectura. Antes del final, inserta en línea aparte: «Sub correctione Santa Matris Ecclesia».]

36) Adriano Modrón, Vaticinio cabalístico anagramático del felice futuro sucesso del parto de la reyna nuestra Señora, en que por vía del Arte Anagramática, de las mismas letras cabales, que forman el nombre, apellido, y titulos de nuestra Reyna, trastocándolas tan solamente, sin añadir, quitar, ni mudar ninguna dellas oy siete de Julio de 1657, pronostica Don Adriano Modrón el año, el mes, y el día mismo, en que su Magestad ha de parir un Principe, Sucessor desta Monarquia, y quán Gran Rey ha de ser en Letras, y Armas, y cómo ha de domar los Rebeldes desta Monarquía, y conquistar, convirtiéndolos a la Fe de Christo, muchos Reynos de Infieles, Moros, y Turcos, y en particular a Tierra Santa, y Jerusalem

- Argumento. NVESTRA SERENÍSSIMA.

- Anagrama. PARIRÁ AL QVARTO PARTO / VN HIJO.

S. 1.; s. i.; s. a., pero: 1657

1 h., doble fol. (290x405 mm)

Madrid, Real Academia de la Historia, 9/3576(76).

[CCPB000418608-7]

Simón Díaz, 1950, XV, no 694; Gonzalo García, pp. 136 y p. 148, reducida. 
[Nota. Orla simple completa de adornos y en su interior el texto poético en la parte superior, dividido por columna de adornos, debajo, enmarcado por filete fino, breve anotación del desarrollo del "Argumento» y del "Anagrama»; a continuación un texto en prosa como explicación dirigido «Al Excelentíssimo señor Conde, Marqués, Duque, \&c. El señor D. Luis de Aro mi señor», firmado por el autor el 29 de noviembre de 1657.]

37) ¿Pedro de Montenegro?, Coplas espirituales para la estrena de la Capilla de Jesús Nazareno en el Colegio de S. Pablo de la Compañia de Jesús de Granada en día de Santo Tomé a 21 de Diziembre de 1680

- [Seguidillas] A IESÚS NAZARENO / Oy se consagra.

S. 1., pero ¿Granada?; s. i.; s. a., pero ¿1680?

1 h., doble fol. $(200 \times 310 \mathrm{~mm})$

Granada, Universidad de Granada, A-31-126(43)

Simón Díaz 1950, XV, no 2.041.

[Nota. Las hojas están impresas a una sola cara; el encabezamiento se repite en cada una de las hojas, sin embargo, parecen que forman una unidad, ya que, a pesar de una posible lectura independiente de cada una de las coplas, parece que se concibe como un poema unitario, y de hecho, la primera seguidilla de la segunda hoja introduce una conexión interestrófica: «Parlan también las aues». Simón Díaz, 1950, XV, no 2041, entrada correspondiente a Pedro de Montenegro, por la anotación manuscrita del ejemplar.]

38) ¿Pedro de Montenegro?, Poesías para la Fiesta, que el Colegio de la Co [m]pañia de Jesús de Granada dedica a la celebridad de la Concepción de $N$. Señora, motivada de el Breve de nuestro Santissimo Padre Alexandro Séptimo, este Año de 1662

- [Seguidillas] ALexandro nos dize, / que es MARÍA hermosa.

Granada; Baltasar de Bolívar; 1662, con el mismo pie de imprenta ambas caras

1 h., doble fol. $(200 \times 310 \mathrm{~mm})$

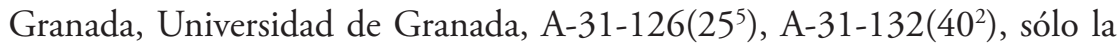
primera hoja y A-31- $\left(45^{2}\right)$, sólo la segunda hoja y A-31-126(423) 
BULLETIN HISPANIQUE

[CСРB00051045-9]

Uriarte, II, no 1585; Palau, X, no 178101; López-Huertas, II, no 436.

[Nota. Las hojas están impresas a una plana, pero el título se extiende por el encabezamiento de ambas, probablemente con la idea de formar un cartel, pues parece que no se concibieron como estrofas independientes ya que en varias ocasiones hay relaciones entre ellas; las estrofas se encuentran enmarcadas por orla completa de adornos. Uriarte, II, no 1585 y Palau, X, no 178101 atribuyen la obra al Padre Montenegro, basándose en las notas manuscritas del ejemplar de la Biblioteca Universitaria de Granada.]

39) ¿Pedro de Montenegro?, Poesías para la Fiesta, que el Colegio de la Compañia de Jesús de Granada dedica a la celebridad de la Concepción de N. Señora, motivada de el Breve de nuestro Santíssimo Padre Alexandro Séptimo, este Año de 1662

- Coplas varias. [Quintillas] TOdo el mundo en este día / celebre, publique, y cante.

Granada; Baltasar de Bolívar; 1662

1 h., doble fol. $(210 \times 315 \mathrm{~mm})$

Granada, Universidad de Granada, A-31-126(25), A-31-132(401) y A-31$132\left(45^{1}\right)$

[CCPB000051045-9]

Uriarte, II, no 1.585, del Padre Pedro de Montenegro; Palau, XIII, no 229745 , indica aparte que son del P. Pedro de Montenegro; López-Huertas, II, no 435 .

[Nota. El título sigue en el encabezamiento de las dos planas y al pie de la segunda se incluyen los datos de impresión; las estrofas se encuentran enmarcadas por orla completa de adornos.]

40) José de Ogazón Angulo, A la augustíssima Reyna de España D. a Maria Ana de Neuburg, haziéndola su reyno reverente llamada a la posse[s]sión de él, en la ocasión de empezar sus festejos, con el plaussible de una Máscara, por hallarse su Magestad capitulada, y para desposarse con el Rey nuestro Señor Carlos Segundo, con quien viva eternidades. Soneto acróstico, empezando cada verso en $A$ y acabando en $A$. Que dedica al Excelentíssimo Señor Condestable 
de Castilla; su vassallo, y menor criado, el Capitán de Infantería Española. D. Joseph de Ogazón Angulo

- [Soneto] Aclamada Deidad, Águila HermosA, / A quien alumbra amor con Nupcial teA

- Otro del mismo autor. [Soneto] DEja tu Oriente, Sol de el Sol Segundo, / Llega al Cénit Hispano, que te espera.

S. 1., pero ¿'Madrid?; s. i.; s. a., pero ¿1690?

1 h., doble fol. (350x410 mm)

Madrid, Biblioteca Nacional de España, VE/200-38

Catálogo, no 676, reducida.

[Nota. Orla completa de adornos, el primer texto inserto entre dos grandes composiciones de adornos que forma la letra «A» $\mathrm{y}$ dividido en su centro por una columna de mayúsculas, rematada arriba y abajo con una «A» capitular floreada, flanqueadas por ocho adornos de cuatro piezas, el otro texto en composición normal flanqueado por dos piezas florales.]

41) José de Ogazón Angulo, Al lamentable fallecimiento de la magestuosa, y florida primavera de la dignissima, y amada Reyna de España Doña María Luisa de Borbón. Dedicado al señor Don Manuel García de Bustamante, Cavallero del Orden de Santiago, y del Consejo de Hazienda de su Magestad, orc. De Don Joseph Ogazón Angulo. Soneto acróstico, rematando en A

- [Soneto] Di, Soberana Flor (que nueva vid A) / Oy el Cielo te ofrece, eternizad A.

- Otro del mismo. [Soneto] PVes en la Regia cumbre, mira el llano / Por vidrieras de llanto, deshojada.

S. l.; s. i.; s. a., pero ¿1689?

1 h., doble fol. $(285 \times 415 \mathrm{~mm})$

Madrid, Biblioteca Nacional de Espańa, VE/24-39

Catálogo, no 677, reducida.

[Orla doble completa de adornos, el primer texto en disposición circular con una «A» tipográfica en el centro, enmarcado en las esquinas con cuatro 
adornos de cuatro piezas, el otro texto en composición normal flanqueado por dos piezas florales.]

42) Poesias al voto que hizieron las escuelas de S. Hermenegildo a la Concepción de María S. N.

- Quartetas del Lic[enciado]. FRANCISCO DE PRADA BARRIENTOS. Vuestra limpieza, y pureza / las escuelas defendemos.

- COPLAS VARIAS. Del Lic[enciado]. Fernando Díaz de Leyba. De María es esta Pascua, / aunque es de Espíritu Santo.

S. 1., pero ¿¿Sevilla?; s. i., s. a., pero 1653

1 h., doble fol. $(200 \times 310 \mathrm{~mm})$

Granada, Biblioteca de la Universidad de Granada, BHR/Caja 2-065(26).

43) Licenciado Diego Ramos del Castillo, Quintillas a la Santa Rosa de Santa María. Compuestas por el Licenciado Don Diego Ramos del Castillo, natural de la Isla de Tenerife, una de las Canarias. Cantólas la Capilla Real en la solemne Octava que se celebró en Santo Domingo el Real de Madrid

- [Quintillas] Pintar quiere el Rosicler / De vna flor de asombros llena.

S. 1., pero ¿Madrid?; s. i.; s. a., pero ¿1669?

1 h., doble fol. $(290 \times 435 \mathrm{~mm})$

Madrid, Real Academia de la Historia, 9/3746(94)

[CCPB000475480-8]

[Nota. Orla completa de dobles adornos, división central con orla triple de adornos. Al fin: «Sub correctione S. R. Ecclesiae, cui quid quid [di]xi subijcio».]

44) Licenciado Diego Ramos del Castillo, Quintillas para un Certamen Poético, y Justa literaria, que se celebró en la siempre Ilustre, y Nobilissima Ciudad de Úbeda, en aplauso de la beatificación de la Santa Rosa de Santa María, compuestas por el Licenciado Don Diego Ramos del Castillo. [Al fin:] Sub Correctione S. R. Ecclesiae, cui quidquid [di]xi subijcio 
- [Quintillas] DOZE quintillas, con pena / Escriuo, y si verdad hablo.

S. 1., pero ¿Madrid?; s. i.; s. a., pero ¿1669?

1h., doble fol. (270x405 mm)

Madrid, Real Academia de la Historia, 9/3746(93)

[CCPB000475481-6]

Gonzalo García, p. 142.

[Nota. Orla completa de dobles adornos, separados con filete, división central con orla simple de adornos; celebración del certamen en 1669, según cartel de convocatoria conservado. Al fin: «Sub correctione S. R. Ecclesiae, cui quid quid [di]xi subijcio».]

45) Licenciado Diego Ramos del Castillo, Redondillas a la Concepción puríssima de Na Sa. Compuestas por el Lic. D. Diego Ramos del Castillo, natural de la Isla de Tenerife, una de las Canarias. Cantáronse en la Capilla Real de Palacio

- [Redondillas] POr culpa del hombre, Dios / padeció por raros modos.

S. 1., pero ¿'Madrid?; s. i.; s. a., pero ¿1669?

1 h., doble fol. $(276 \times 420 \mathrm{~mm})$

Madrid, Real Academia de la Historia, 9/3727 (2)

[CCPB000475641-X]

[Nota. Orla simple completa de adornos, texto a dos columnas, divididas por doble columna central de adornos. Al fin: Sub correctione Sancta Martris Ecclesia, cui quidquid [di]xi subijcio. Atribuimos, provisionalmente, la fecha por tratarse del mismo autor que compone un poema al certamen de Úbeda a Santa Rosa de Lima (1669).]

46) Agustín Ceferino Rodríguez Manzano, Laberinto de la mejor salida, pues en ella incluye un Cathólico aviso, que se da al pecador obstinado, el qual se repite diversas vezes por todos sus renglones, empezando siempre por la letra que 
está enmedio. Dedícale al señor Don Antonio Pérez de la Puente, Cavallero del Orden de Santiago, del Consejo de Su Magestad, en el Real de Hazienda; Don Agustín Ceferino Rodríguez Manzano, su más afecto servidor

- [Redondilla] Si empezares por la N, / Que es centro del Laberinto.

- [Laberinto] Número tiene el pecar, / No le llegues a llenar.

- GLOSSA. MOrtal, si en el ciego abismo, / En que tus culpas te tienen.

- OTRA GLOSSA. EL Diuino Amor intenta / Dar tiempo a todo mortal.

S. l.; s. i.; s. a., pero después de 1684

1 h., doble fol. $(310 \times 410 \mathrm{~mm})$

Madrid, Biblioteca Nacional de España, VE/501-33

Catálogo, no 849, reducida.

[Nota. Orla sencilla completa, en el centro composición cuadrada tipográfica enmarcada por orla completa de adornos, flanqueada por los restantes textos, divididos estróficamente por línea de adornos,]

47) Romance al hijo de María, fuente de la Gracia, San Juan Evangelista en el martirio de la tina: fiesta que celebran los impressores desta coronada Villa de Madrid en el convento de N. Señora del Carmen Calzado el día seis de mayo - [Romance] EXcelsa, Gloriosa FVENTE, / Cuyos Raudales fecundos.

Madrid; En la Imprenta de Anastasio Abad, por Antonio Román; 1683

1 h., doble fol. (310x395 mm)

Madrid, Real Academia de la Historia, 9/3656(13).

[CCPB000425017-6]

Agulló y Cobo, 1966, ed., pp. 170-171 y [lám.], reducida.

[Nota. Dos tintas, orla completa de adornos y en el interior composición en forma de fuente de adornos, con dos estampetas de jarrón en los remates laterales de la base; el texto a una columna en sus flancos.] 
48) Rosa de Santa María

- [Quintillas en serie, seguidas de serie de redondillas] Rosa de Santa María, / no es sola la deuoción.

S. 1., pero ¿Granada?; s. i.; s. a., pero ¿1668?

1 h., doble fol. $(310 \times 415 \mathrm{~mm})$

Madrid, Archivo Histórico Nacional, Clero regular y secular, Libro 3852.

[Nota. Texto enmarcado en orla completa de adornos con divisiones verticales de adornos que separan el texto en tres columnas; en la parte superior, entre adornos en vertical: "ROSA DE», «SANTA MARIA.» y en el centro adorno floral; es posible sugerir que el poema se refiera a la celebración de la Beatificación de Santa Rosa de Lima celebrada en Granada en 1668.]

49) Sumario de vida christiana, escala del cielo, y guia de perfección

- [Coplas de pie quebrado] ¿Quién truxo a Dios a la tierra? / Tu miseria.

- [Terceto] Alma está vigilante, / Atiende a la perfección.

Madrid, José Fernández de Buendía, Véndese en la calle de Toledo, junto al Colegio de la Compañía de Jesús, en casa de la viuda de Antonio de Castilla, Mercader de Libros, 1660.

1 h., doble fol. $(245 \times 355 \mathrm{~mm})$

Madrid, Biblioteca Nacional de España, VE/184-22

Simón Díaz, 1986, nº 24.

[Nota. Orla completa de adornos, inserta grabadito de la Crucifixión orlada, los textos divididos por líneas de adornos horizontales.]

50) ¿Juan Francisco de Torres?, Coplas en alabanza de la Inmaculada Concepción de N. a S. ${ }^{a}$

- [Sextillas] POr divino privilegio / tan nuevo, y tan singular.

Madrid; Julián de Paredes; 1652

1 h., doble fol. $(260 \times 410 \mathrm{~mm})$ 
Madrid, Real Academia de la Historia, 9/3727(11) [CCPB000465798-5]

[Nota. Orla simple completa de adornos, encabezada por estampeta de la Virgen, flanqueada por dos rombos de adornos, texto a cuatro columnas, divididas por filete fino. Anotación manuscrita al pie: "Compuestas por el licenciado Juan Francisco de Torres». Al fin: "CON LICENCIA». Nota manuscrita abajo: "Ynprimase con que no sean las siete últimas coplas y con que se traiga la copia para ver si coresponde [sic] con su original [firma: ¿Don Ro ar [ilegible]»; debajo, de otra letra, con el inicio de cada línea cortado: «[...]primirse sin las siete coplas. Madrid y [...] de 1662.]

51) Juan Casimiro de Velasco Vizcaíno, Al tan sentido, quanto lamentable fallecimiento de la Reyna nueslra [sic] señora Doña María Luisa de Borbón, laberinto en soneto, rematando en A. Dedicado a don Baltasar García de los Reyes, Contador de millones, y rentas reales de Plasencia. De don Juan Casimiro de Velasco Vizcaino, estudiante theólogo en dicha ciudad

- [Soneto] Acróstico. DIO fiN la humanA luz, que Más luzía; / O feudO o pensióN ciertA hórrida Muerte.

S. 1., pero ¿Madrid?; s. i.; s. a., pero, ¿1689?

1 h., doble fol. $(265 \times 385 \mathrm{~mm})$

Madrid, Biblioteca Nacional de España, VE/68-91

Catálogo, no 1.024 , reducida.

[Nota. Orla triple completa de adornos, el texto compuesto en dos disposiciones, los primeros siete versos por líneas con acróstico tipográfico de mayúsculas inicial y medial y los siete siguientes en forma radial con remates de mayúsculas tipográficas, flanqueados por dos figuras en forma de obeliscos de adornos,]

52) Vizconde de San Miguel y de Otero, Soneto acróstico a la muerte de la Reyna nuestra Señora doña María Luisa de Borbón, que goza de Dios, del Vizconde de San Miguel, y de Otero. Ofrécele rendido Al señor Don Manuel Garcia de Bustamante, Cavallero del Orden de Santiago, del Consejo de Hazienda de su Magestad 
- De la fábrica ruda de el torment O / O bl[¿iigada?] de la angustia de el cuidad $\mathrm{O}$.

S. 1., pero ¿Madrid?; s. i.; s. a., pero ¿1689?

1 h., doble fol. $(295 \times 415 \mathrm{~mm})$

Madrid, Biblioteca Nacional de España, VE/24-20

Simón Díaz, 1977, lám. no [5], reducida; Catálogo, no 901, reducida.

[Nota. Orla doble completa de adornos, el texto en disposición circular, con una «O» tipográfica central y mayúsculas de tipo más grande en la última letra, enmarcado en las esquinas con cuatro adornos de cuatro piezas.] 


\section{BULLETIN HISPANIQUE}

\section{REFERENCIAS BIBLIOGRÁFICAS DEL INVENTARIO}

Aguilar Piñal = Francisco Aguilar Piñal, Bibliografía de autores españoles del siglo XVIII, Madrid, CISC, 1981-2001, 10 ts.

Agulló y Cobo, 1966 = Mercedes Agulló y Cobo, 1968, «Noticias de impresores y libreros madrileños de los siglos XVI y XVII", Anales del Instituto de Estudios Madrileños, I, 1966, p. 169-208, con una hoja de láminas entre p. 192 y 193.

— 1967 = «Noticias de impresores y libreros madrileńos de los siglos XVI y XVII (Continuación)», Anales del Instituto de Estudios Madrileños, II, 1967, p. 175213.

— 1968 = «Noticias de impresores y libreros madrileños de los siglos XVI y XVII (Continuación)», Anales del Instituto de Estudios Madrileños, III, 1968, p. 81116, con dos hojas de láminas encartadas entre pp. 112-113.

— 1969 = «Textos», Anales del Instituto de Estudios Madrileños, IV, 1969, p. 469474.

Batlle = Juan Bautista Batlle, Los goigs a Catalunya. Breus consideracions sobre son origen y sa influència en la poesía mistica popular. Acompayan a aquesta obra cent facsimils reproduit de goigs estampats en lo segle XVII, Barcelona, Imprenta Altés, 1924.

Catálogo = Catálogo de pliegos sueltos poéticos de la Biblioteca Nacional Siglo XVII, Madrid, Universidad de Alcalá de Henares/Ministerio de Educación y Cultura, 1998.

Cózar = Rafael de Cózar, Poesía e imagen. Formas difíciles de ingenio literario, Sevilla, El Carro de Nieve, 1991.

Díez Borque, 1992 = José Ma Díez Borque, ed., Literatura de la celebración. Verso e imagen en el Barroco español, Madrid, Capital Europea de la Cultura, 1992.

— 1999 = «Poesía en la calle (de los Siglos de Oro al Siglo de las Luces)», en Andrés Amorós y José Ma Díez Borque, Historia de los espectáculos en España, Madrid, Castalia, 1999, p. 419-454.

García de Enterría = Ma Cruz García de Enterría, «Retórica popular y retórica culta en el Barroco: un texto de 1662», Studi Ispanici, 1987, p. 229-246, con encarte entre p. 242-243.

Gisbert/Ortells = Ana Gisbert Terol y Ma Lutgarda Ortells [Pérez], Catálogo de obras impresas en el siglo XVII de la Biblioteca Histórica de la Universitat de València, Valencia, Universidad de Valencia, 2005.

Gonzalo García = R. Consuelo Gonzalo García, "Sucesos mayores en impresos menores: el nacimiento del príncipe Felipe Próspero (1657)", Rivista di Filologia e Letterature Ispaniche, II, 1999, p. 133-147.

Imagen = Imagen del verso. Del Siglo de Oro al siglo XX, Madrid, Biblioteca Nacional, 2008. 
Infantes, 1996 = Víctor Infantes, ed., Poesía matemática (Un cartel poético para el Rey), Mataró, Vèrtex, 1996.

- 2002 = ed., Un cartel tipográfico del Siglo de Oro. Al águila misteriosa San Juan Evangelista, Madrid, Ediciones de la Imprenta/Memoria Hispánica, 2002.

- 2005 = «La santidad tipográfica en la España del Siglo de Oro. Las honras poéticas a San Juan Evangelista, Patrón de los Impresores», Peninsula. Revista de Estudos Ibéricos, 2, 2005, p. 251-296.

Jerez de los Caballeros = Manuel Pérez de Guzmán y Boza, Décimas a la Inmaculada Concepción de Nuestra Señora de diferentes autores, Sevilla, E. Rasco, 1888 [= Whitefish, Kessinger Publishing, 2010].

López-Huertas Pérez $=\mathrm{M}^{\mathrm{a}}$ José López-Huertas Pérez, Bibliografía de impresos granadinos de los siglos XVII y XVIII, Granada. Universidad de Granada/ Diputación Provincial de Granada, 1997, 3 ts.

Muriel = Felipe Muriel, «Pintar con la palabra (I)», Séneca Digital. Revista digital del IES Séneca, 2, abril 2009.

Palau = Antonio Palau y Dulcet, Manual del librero hispanoamericano, Barcelona/ Oxford, Antonio Palau/The Dolphin Book, 1948-1976, 28 ts.

Paredes = Alonso Víctor de Paredes, Institución y origen del Arte de la Imprenta y reglas generales para los componedores, Jaime Moll, ed. $\mathrm{y}$ «Nueva noticia editorial» de Víctor Infantes, Madrid, Calambur, 2002.

Simón Díaz, 1950 = José Simón Díaz, Bibliografía de la literatura hispánica, Madrid, CSIC, 1950-[1994], 16 ts.

- 1977 = La poesía mural en el Madrid del Siglo de Oro, Madrid, Ayuntamiento de Madrid, 1977.

- 1982 = "Algunos carteles poéticos del Siglo de Oro», Cuadernos Bibliográficos, XLIV, 1982, pp. 201-203.

— 1983 = El libro español antiguo: análisis de su estructura, Kassel, Reichenberger, 1983.

— 1986 = «Algunos impresos madrileños raros de la segunda mitad del siglo XVII", Anales del Instituto de Estudios Madrileños, XXXIII, 1986, p. 517-545.

Uriarte = José Eugenio de Uriarte, Catálogo razonado de obras anónimas y seudónimas de autores de la Compañia de Jesús pertenecientes a la antigua asistencia española, con un apéndice de otras de los mismos, dignas de especial estudio bibliográfico, Madrid, Sucesores de Rivadenyra, 1904-1916, 5 ts.

Verso e imagen $=$ Verso e imagen. Del Barroco al Siglo de las Luces. Exposición, febreromarzo 1993, Madrid, Calcografía Nacional, 1993. 


\section{ÍNDICE DE PRIMEROS VERSOS}

A Jesús Nazareno $\quad 37$

A la escuela de Aquino muchachos 8

A la más gloriosa pluma $\quad 7$

A mi discurso la fe $\quad 14$

A mi vida traspassé $\quad 42$

A no rociar aromas 1

Aclamada deidad águila hermosa $\quad 40$

Águila excelsa y divina $\quad 15$

Al florido mayo los labradores $\quad 35$

$\mathrm{Al}$ infundiros el alma $\quad 27$

Al sagrado jubileo $\quad 20$

Alexandro nos dice $\quad 38$

Alma está vigilante $\quad 51$

Cándida brillante rosa 4

Con la a roxa que empieces 1

Confiessa ese pecado 26

Confiéssate pecador 29

Contar quiero las virtudes 5

Corazones almas fieles $\quad 32$

Coronada la belleza $\quad 11$

Cuando tu curiosidad 28

De gracia en vuestra pureza 27

De gracia y socorro son $\quad 19$

De Juan la sacra memoria 2

De la fábrica ruda del tormento $\quad 52$

De María es esta Pascua $\quad 42$

De nuestra Fe en el Jardín $\quad 10$

De títulos y grandezas 24

Deja tu Oriente sol del sol segundo $\quad 40$

Del sacro honor de Maria $\quad 27$

Del monarca de luz rapto portento 23

Di soberana flor que nueva vida $\quad 41$

Dio fin la humana luz que más lucía $\quad 51$

Doce quintillas con pena $\quad 44$

El autor deste romance 20

El divino amor intenta 46

El duro yugo del rigor violento 25

El nombre de santo quadre 22 
En aqueste ingenioso laberinto $\quad 18$

En la casa del que jura $\quad 26$

En presencia de la cabeça $\quad 35$

Es San Juan cáliz que encierra $\quad 12$

Esta sagrada imagen de María 20

Este estruendo militar $\quad 13$

Excelsa gloriosa fuente $\quad 47$

Gertrudis Virgen gloriosa 34

$[\mathrm{H}]$ oy mi Talía se inclina $\quad 6$

Libre fue vuestra hermosura $\quad 27$

Los claveles y rosas $\quad 35$

Los elegantes aromas $\quad 1$

Luz del orbe reluciente $\quad 16$

Mira que te mira Dios 26

Mortal si en el ciego abismo 46

Nace a su ocaso, sol de gloria alado 19

Nazes al nido de Aquino $\quad 10$

Número determinado $\quad 26$

Número tiene el pecar $\quad 46$

$\mathrm{O}[\mathrm{h}]$ dichosa hermandad apostolado 19

¡Oh dichosos sagitarios! 35

$\mathrm{O}[\mathrm{h}]$ divina emperadora 34

$\mathrm{O}[\mathrm{h}]$ Reina obscurecida, [...] velo 23

Oí palpé gusté vi y tuve olfato 31

Oy mi Talía se inclina 6

Parirá al cuarto parto 36

Patara dicha ha logrado $\quad 17$

Piensa que te has de morir 29

Pintar quiero el rosicler 43

Plaça estrellas del Olimpo $\quad 10$

Podemos decir de Dios 3

Poder eterno a qué agrado 13

Por culpa del hombre Dios $\quad 45$

Por sacarte de cuydado $\quad 30$

Por divino privilegio $\quad 50$

Prodigiosíssimo enigma $\quad 11$

Pues en la regia cumbre mira el llano $\quad 41$

Puesto que entre los mayores $\quad 17$

Quando tu curiosidad véase Cuando tu curiosidad 
Quién truxo a Dios a la tierra

Rendidos dos corazones

6

Rosa de Santa María 48

Si con los fieles difuntos

26

Si empezares por la $n$

46

Si quieres ver el fin triste que espera

31

Silencio señores míos

8

Soberano invicto mártir

9

Términos tienen los días

21

Thomás fuente de la Fe

Tomás fuente de la Fe

Tomás fuente de la Fe

Todo el mundo en este día 16

Un pintor en esta corte

32

Va de Víctor estudiantes

26

Voz impura el arrebol

Vuestra limpieza y pureza

42

Yo cómo vine al mundo condenado

31

Yo para qué nací para salvarme

27 


\section{ENTREMÉS DEL CARTEL}

Salen Ignacio, Bachiller, y ALmudena, Hilandera; media mañana en una calle de la Judería de Córdoba.

IGNACIO.

Muy entretenida veo a mi señora vecina doña Almudena con ese papelón que han pegado en la pared.

\section{Almudena.}

Y bien que lo diga, don Ignacio, que estoy probando mi paciencia con letra tan menuda.

IGNACIO.

Si me permite acercarme, yo también quiero ver qué dice ese cartel, que puede ser cosa de interés y enjundia.

Almudena.

Pues lo dudo, porque no se trata de Edicto ni Premática, que hay más versos que prosas y eso ya señala que hay que prestar poca atención, que nada grave va a anunciar que interese a la hacienda o a la bolsa.

IGNACIO.

Pero sí al alma y a los sentimientos, que las informaciones de la autoridad pueden no sernos útiles para nada provechoso, pero la poesía siempre allega un reposo para el espíritu y el sosiego.

Almudena.

Eso ... si pudiera leer lo que dice, porque mucho adorno, mucha cruz y mucha flor por todas las esquinas, pero los versos andan escondidos entre tantos corazones. 
IGNACIO.

¡Ay, cómo me alegra, doña Almudena, que piense que la poesía se esconde en el corazón!, que sé que es mujer de formación y de buenas letras.

\section{Almudena.}

No, señor Ignacio, no, me refería a que no hay quien pueda leer los versos, porque, aparte de la letra tan menuda, están metidos dentro de esos adornos en forma de corazón, que mi cuñado impresor llama pimientos, que rodean este romance por todas las partes, y que, sin contarlos, pues no me llegan ya los ojos para sumar sandeces, han debido gastarse todos los que tenían en el taller.

\section{IGNACIO.}

¡Pero ... y lo bonito que queda el poema, rodeado y flanqueado de tanta gala y aderezo!, parece un marco de pan de oro para la inspiración de quien lo creó, y a buen seguro que el autor, del que tampoco veo su nombre por ninguna línea, estará más dichoso con esta presencia, que ver su poema en la desnuda página de un pliego, de esos de medio real, a los que es tan aficionada.

\section{Almudena.}

No, si bonito ..., sí que queda, sí, pero hay que meter las narices a medio palmo del cartelón para leer lo que su musa le dispensó para este asunto, por eso me vengo a primera hora a ver esta maravilla, que nadie hay todavía formando corro y puedo sin prisas mirar este bodegón.

IGNACIO.

¿Bodegón he oído que ha dicho doña Almudena?

Almudena.

Esas han sido mis palabras, que esos artificios de papel barato que hoy está aquí y mañana han volado a las acequias me parece bodegones de letras muertas y bien muertas, sin nombres de autor y más efímeros que el soplar un candil. Todos llenos de hojas, florones y floreros, y así las pobres letras 
parecen cagarrutas de tintero. Yo prefiero sentarme en mi silla de labores y leer sin prisa esos pliegos que antes mencionaba, que les doy vueltas y más vueltas para enderezar su sentido y cuando me canso de coplas y de glosas, los doblo a mi comodidad y me los guardo en la faldriquera para otra ocasión más propicia, pero siempre puedo volver a ellos cuando me tientan las rimas y tengo un rato de descanso en mis pesares. Pero estas hojas tan floridas me incomodan en extremo, me tengo que pelear por acercarme a su cara, ando de pie sin apoyos y si no me doy prisa, a la tarde ya no están, y me quedo sin saber qué decían y para qué andaban impresas. Por eso, las más de las veces, me contento, y no poco, en mirarlas de lejos, para no tener contienda con nadie que anda con los ojos pegados a su frente; y desde donde los miro, se me asemejan a bodegones de tinta, más muertos que vivos y, las más de la veces, sin sustancia ni provecho.

IgNACIO.

Pero, doña Almudena, bien es verdad que estos cartelones están impresos con esmero y cuidado, que mucho empeño ponen en ellos los talleres de imprenta...

Almudena.

Perdone que le interrumpa, don Ignacio, pero en casi ninguno he visto nunca nombre del artífice ni del taller de donde salió ni la fecha del arrebato poético.

IGNACIO.

Sí, lleva razón en ello, pero es que a casi ningún autor, salvo cuando se trata de loar a los reyes, autoridades y religiosos, se le ocurre en estos tiempos dar sus apellidos a obrillas tan fugaces y tan del uso común, y también es verdad que a quienes los componen, imprimen y editan, iy vaya a saber a cuenta de quién y por qué!, les importa bien poco que su nombre figure, y las más de las ocasiones se les olvida con las prisas y los plazos, salvo cuando hay otros intereses por medio y entonces bien que señalan hasta la calle donde tiene el taller y la festividad del día que pusieron el lausdeo. Pero volviendo a lo de antes, he de decirle, por lo de los adornos y bodegones, que son buena muestra de adónde ha llegado este arte de la Imprenta en nuestra ciudad, que es honra para muchos hombres que escriben y publican, y ven así, con galano oficio, reproducidos sus pensamientos con claridad y buen gusto, $y$ a todos hace buen servicio que no tengan que ir a publicar sus obras a otras ciudades. Crea V.M., que ese ornato es maravilla, y lo que ponga 
dentro se lee con más alegría y disposición. Y no olvide, doña Almudena, que nada nos cuestan, y son de las pocas veces que la poesía nos sale gratis a los buenos aficionados, y que hay para todo y para todos, como dejó dicho don Juan hace ya muchos decenios: de exequias, de honras, de devoción, de plegarias, de certámenes y, en general, todos han pasado censura eclesiástica y no contienen errores ni desatinos.

\section{Almudena.}

Si no le digo que no, don Ignacio, pero a mí me gusta más papel en mano, sujeto y seguro, que carteles en la pared sólo para el día de la fiesta, que si quiere uno volver a leerlos otro día, están ya guardados en las sobras de la basura. ¡Tantos cuartos, ingenio y esfuerzos para pasar al olvido en cuanto cae la noche y sólo los miran las sombras!

\section{IGNACIO.}

En eso lleva razón, pero no se apure que imprimen pocos, salvo los que encargan y compran al por mayor algunas cofradías para hacer república de sus favores, pero dan mucho gusto a tantos y a muchos más les procura provecho de la imaginación, que a más de uno he visto mirar el cartel, leer los versos, repetirlos, comentarlos a los otros y volver a sus ocupaciones recitando en la memoria sus figuras y sus afectos, más felices que unas pascuas de haber tenido su ración de poesía.

\section{Almudena.}

¡Ay! ¡Demasiados poetas y demasiados versos ven estos tiempos!, que no hay ojos suficientes para leer tanta imaginación.

\section{IGNACIO.}

¿Y eso lo dice quien no repara gasto de relaciones, romances y canciones?, que bien sé que pierde buenos reales en alimentarse de poesía y de devoción.

\section{Almudena.}

Pero me duran más tiempo y los guardo como beneficio de mi ocio y a ellos vuelvo, como V.M. a sus cartapacios y librotes, sin estos agobios de la calle, cuando quiere mi recreo, y le recuerdo, don Ignacio, que mi cuńado impresor me los saca a precio de saldo, cuando ya han cumplido la tirada. 
IGNACIO.

Pues buen recaudo haga, dońa Almudena, de todas esas coplas, que no hace falta ni encuadernar ni pegar, que yo mis libros los tengo bien cosidos, y estos carteles me alegran el paseo, y sigo camino abajo recitando en silencio quintillas, cuartetas y sonetos y recordando el artificio de laberintos, acrósticos y figuras. La dejo, pues, en compañía de este cartelón, porque marcho hacia el Hospital, que hay ahora sesión de Estudio de una ilustre Academia y hablan y discuten de poesía.

\section{Almudena.}

Pues que le haga provecho, aunque yo creo que la poesía es sólo para mirar y leer y que hablar mucho de ella causa fatiga, y a pocas razones se llegan por mucho que se discuta sobre su ingenio y composición.

\section{IGNACIO.}

Razón lleva en ese juicio, doña Almudena, pero me han dicho que todos los allí reunidos son varones de mucho estudio venidos de otros reinos y lugares, de muchas luces, y de muchos saberes y algo aprenderé de sus disputas, y que incluso, para esta ocasión tan celebrada, han hecho laudo con alguna académica y asombro será oír a una mujer tratar de poesía.

\section{Almudena.}

Ya me contará, entonces, a qué veredictos llegan y ¡ojalá! que alguno acierte a explicar el porqué de tanta poesía y de tantos papeles pegados en los muros a cada puerta y cada lienzo.

\section{IGNACIO.}

Pues le haré un resumen si al final me entero de lo que disertan, que si clara debe ser la poesía, oscura parece que es siempre la forma de explicarla.

Almudena.

Buen día tenga, entonces, y en eso quedamos. 


\section{BULLETIN HISPANIQUE}

IGNACIO.

Igual le deseo, y mañana espero encontrarla de nuevo aquí, que me han dicho que salen los carteles de San Juan y esos sí que son una alegría de los ojos.

Almudena.

En eso sí lleva buena razón, que los del año pasado todavía los tengo en la memoria de lo bien adornados que estaban, con altares, águilas, copas y grabados por todos los papeles, pero en lo de los poemas poco empeño pusieron, que en el olvido se me quedaron todos y nada he perdido yo desde entonces. 